\title{
The Civil Nonjury Trial and the Law-Fact Distinction
}

\author{
Stephen A. Weiner*
}

TN A PRIOR ARTICLE this author suggested that the distinction between 1 questions of law and fact was by itself an inadequate basis for allocating decision making between judge and jurors in the civil jury trial. ${ }^{1}$ A question of identifying broadly formulated principles for judging the parties' conduct can meaningfully be defined as a question of law for the trial court. ${ }^{2}$ A question of reconstructing acts or events which have actually taken place, or conditions which have actually existed, can meaningfully be defined as a question of fact for the jury. ${ }^{3}$ In addition to resolving questions of this kind, however, the typical case requires a decision inaker to apply the general to the specific, that is, to appraise an established set of historical facts in terms of controlling law. ${ }^{4}$

A simple illustration of these three categories may be useful. A judge declares law when he states that a defendant master is hable for a tort of a servant acting within the scope of his einployment. A jury finds facts when it identifies those acts of the servant which culminated in the tort. But either judge or jury must also decide whether the tort was within the scope of the servant's employrnent.

This third category of law application supplements the traditional law and fact categories; policy factors should determine whether a specific example of law application belongs to judge or jury. ${ }^{5}$ Law application should generally be a jury function because of the constitutionally supported policy favoring trial by jury. ${ }^{6}$ However, a judge may be so much more competent than a jury to apply a particular legal standard that he should assume the task. ${ }^{7}$ Similarly, a compelling need in certain cases for uniformity may justify excluding the jury from law application. ${ }^{8}$

* A.B., 1954, Harvard University; LL.B., 1957, Yale University. Acting Professor of Law, University of California, Berkeley.

${ }^{1}$ Weiner, The Civil Jury Trial and the Law-Fact Distinction, 54 CaLIF. L. REv. 1867 (1966).

2Id. at 1869.

3 Id. at $1869-70$.

4 Id. at 1871.

5Id. at 1918-19.

6 Id. at 1919-21.

7 Id. at $1922-23$.

8 Id. at $1924-25$. 
$\mathbf{I}$

THE NONJURY TRIAL

The well-entrenched dichotomy between "legal" and "factual" questions in the civil jury trial also arises in the civil case tried without a jury. ${ }^{9}$ At the trial stage of the nonjury case, the law-fact distinction will be of little significance, since all decision making, whatever its label, is performed by a single judge. The judge, in preparing his written opinion, may be required to state findings of fact and conclusions of law separately; ${ }^{10}$ mistaken labelling of a particular holding, however, will be of minor consequence. ${ }^{11}$ The classic law-fact distinction becomes crucial only when the judge's decision is appealed. In the federal court system, the trial judge's "finding of fact" is entitled to special weight; pursuant to Federal Rule of Civil Procedure 52(a), it "shall not be set aside unless clearly erroneous." ${ }^{\prime 2}$ In contrast, a federal appellate court may reverse a judge's "conclusion of law" if it simply disagrees with the trial judge. ${ }^{13}$

States hike California, which lack a statutory provision comparable to Federal Rule 52(a), reach a similar result through frequently reiterated case law on the scope of appellate review. The appellate courts claim that they do not decide "questions of fact," only "questions of law." "The dichotomy is not absolute; a "factual" finding by the trial judge may be reversed as a "legal" error if not supported by substantial evidence." However, an appellant must sustain a heavy burden in establishing that no substantial evidence buttresses the finding under attacks. ${ }^{16}$ State and federal appellate courts pay far greater deference to a trial judge's finding of fact than to his legal conclusion.

9 The trial may proceed without a jury because equitable issues alone are presented, the case is one in admiralty, or the parties have waived any right to jury trial.

10 See, e.g., Car. Code Cw. Pro. § 632 (West 1955), as amended, (West Supp. 1966). FED. R. Crv, P. 52(a) provides that "the court shall find the facts specially and state separately its conclusions of law thereon," but this command is tempered by a later sentence, added in 1946, that "[i]f an opinion or memorandum of decision is filed, it will be sufficient if the findings of fact and conclusions of law appear therein." See generally Note, The Law of Fact: Findings of Fact under the Federal Rules, 61 HARv. L. Rev. 1434 (1948).

11 E.g., Houck v. Hinds, 215 F.2d 673, 676 (10th Cir. 1954); Benrose Fabrics Corp. v. Rosenstein, 183 F.2d 355, 357 (7th Cir. 1950) ("true nature" of trial judge's holdings "not determined by their labels"); Johndrow v. Thomas, 31 Cal. 2d 202, 205, 187 P.2d 681, 683 (1947); Lenchner v. Chase, 98 Cal. App. 2d 794, 802, 220 P.2d 921, 925 (1950).

12 In elaborating on the standard specified in Rule 52 (a), the Supreme Court has stated: "A finding is 'clearly erroneous' when although there is evidence to support it, the reviewing court on the entire evidence is left with the definite and firm conviction that a mistake has been committed." United States v. United States Gypsum Co., 333 U.S. 364, 395 (1948).

13 See 5 J. Moore, Federal Practice II 52.03[2] (2d ed. 1966).

14 E.g., Tupman v. Haberkern, 208 Cal. 256, 280 P. 970 (1929).

15 E.g., Hall v. Osell, 102 Cal. App. 2d 849, 853, 228 P.2d 293, 296 (1951).

16 See, e.g., Estate of Bristol, 23 Cal. 2d 221, 223-24, 143 P.2d 689, 690 (1943). 
Many determinations of a trial judge involve neither reconstruction of past events or conditions nor declaration of broadly formulated principles controlling the case before him. Rather, they may fall in the third category of law application; the judge may be relating the governing legal standard to particular historical facts. If such a decision is appealed, the appellate court must classify it as law or fact, thereby establishing whether it is freely reviewable. ${ }^{17}$ Since law application cannot be meaningfully described as either lawmaking or factfinding, such terminology is not a useful analytical tool in answering the question confronting the court. ${ }^{18}$ Accordingly, the appellate court may simply declare, without further comment, that the question is one of law or one of fact. ${ }^{19}$ Presumably, if the court feels that a trial judge's determination should be reversed, it will classify it as a legal conclusion, thereby making reversal easier. ${ }^{20}$ Some courts, relying on cases allocating decision making in the jury trial, have tacitly assumed that a question of law application considered as factual for the jury should necessarily be regarded as factual for the trial judge. ${ }^{21}$ Similarly, some courts assume that an example of law application considered a question of law for the presiding judge at a jury trial should receive the same classification in the nonjury case. ${ }^{22}$ Only a few decisions have considered whether the trial judge's application of the law should, as a matter of policy, be given special weight. ${ }^{23}$

Not surprisingly, both federal and state cases clash hopelessly in classifying law application by a trial judge as a factual or legal matter. ${ }^{24}$

17 "Abstractly classifying the question as factual or legal really expresses a segregation of function ainong the trinity of tribunals . . . involved in the decisional process. 'The question is,' as Humpty Dumpty remarked, 'wbich is to be master-that's all." Yakov v. Board of Medical Examiners, 250 A.C.A. 271, 280, 58 Cal. Rptr. 644, 649-50 (1967) (Bray, J.), hearing granted, Sac. 7810, 66 A.C. Minutes 1 (July 14, 1967). See generally Rice, Law, Fact, and Taxes: Review of Tax Court Decisions Under Section 1141 of the Internal Revemue Code, 51 Colum. L. Rev. 439 (1951).

18 Cf. Baumgartner v. United States, 322 U.S. 665, 670-71 (1944).

19 E.g., Pacific Inland Navigation Co. v. Course, 368 F.2d 540, 542 (9th Cir. 1966); Bryan v. Kersbaw, 366 F.2d 497, 499 (5th Cir. 1966); United Air Lines, Inc. v. Wiener, 335 F.2d 379, 401-02 (9th Cir. 1964); Green v. Bluff Creek Oil Co., 287 F.2d 66, 69 (5th Cir. 1961).

20 The opposite possibility is also a real one: "Calling a judge's legal conclusion a finding of fact is an all too easy way for appellate judges to obscure or even avoid legal issues when the result of the trial suits them." Ruby v. American Airhines, Inc., 329 F.2d 11, 23 (2d Cir. 1964) (dissenting opinion of Friendly, J.), vacated as moot sub nom. O'Connell v. Manning, 381 U.S. 277 (1965).

21 E.g., Bogue Elec. Mfg. Co. v. Coconut Grove Bank, 269 F.2d 1, 4 (5th Cir. 1959). See also text accompanying notes 30-40 infra.

22 See notes 142-48 infra and accompanying text.

23 See notes $41-45,91$ infra and accompanying text.

24 Texas Co. v. R. O'Brien \& Co., 242 F.2d 526, 529 \& n.1 (1st Cir. 1957); C. Wright, HANDBOOK OF THE LAW OF FEDERAL COURTS \$ 96, at 375-77 (1963); Stern, Review of Findings of Administralors, Judges and Juries: A Comparative Analysis, 58 HARv. L. Rev. 70, 94-95, 
Federal courts of appeals disagree with one another, ${ }^{25}$ and even single circuits, ignoring conflict in their own opinions, have applied Rule 52(a) inconsistently. ${ }^{26}$ Different circuits cannot agree whether the trial court's holding is a finding of fact or a conclusion of law even in identical examples of law application. ${ }^{27}$ Clearly, this bewildering pattern dictates

117-19 (1944); Note, Rule 52(a): Appellate Review of Findings of Fact Based on Documentary or Undisputed Evidence, 49 VA. L. Rev. 506 (1963); compare, e.g., Husky HiPower, Inc. v. Salt Creek Freightways, 366 P.2d 1003, 1006-07 (Wyo. 1963), with, e.g., Shultes v. Halpin, 33 Wash. 2d 294, 306, 205 P.2d 1201, 1207 (1949).

25 Compare, e.g., In re Kellett Aircraft Corp., 186 F.2d 197, 200 (3d Cir. 1950) ("So far as the disposition of this case requires us to draw legal conclusions or inferences from undisputed facts, the rule [52(a)] is not relevant."), with Lewis v. Super Valu Stores, Inc., 364 F.2d 555, 556 (8th Cir. 1966) ("The clearly erroneous standard . . . applies to reasonable inferences to be drawn from stipulated or undisputed facts, and it is for the trial court rather than the appellate court to draw legitimate and permissible inferences.").

26 This is particularly true of the Ninth Circuit. See notes 63-67, 132, 141, 154, 195-204 infra and accompanying text; Lundgren v. Freeman, 307 F.2d 104, 114-15 (9th Cir. 1962). As for other circuits, compare Goldberg v. P. \& L. Equip. Co., 311 F.2d 88, 89 (5th Cir. 1962), and Galena Oaks Corp. v. Scofield, 218 F.2d 217, 219 (5th Cir. 1954), and Stubbs v. Fulton Nat'l Bank, 146 F.2d 558, 560 n.1 (5th Cir.), cert. denied, 325 U.S. 864 (1945), with National Sur. Corp. v. Wells, 287 F.2d 102, 107 (5th Cir. 1961), and Tennessee Coal, Iron \& R.R. v. Muscoda Local 123, 137 F.2d 176, 180 (5th Cir. 1943), aff'd, 321 U.S. 590 (1944); compare Taft Broadcasting Co. v. Columbus-Dayton Local, Am. Fed'n of Television \& Radio Artists, 297 F.2d 149, 152 (6th Cir. 1961), and Seagrave Corp. v. Mount, 212 F.2d 389, 394 (6th Cir. 1954), and Walling v. Nashville, C. \& St. L. Ry., 155 F.2d 1016, 1018 (6th Cir. 1946), with Carr v. American Universal Ins. Co., 341 F.2d 220, 224 (6th Cir. 1965), and Bale v. Glasgow Tobacco Bd. of Trade, Inc., 339 F.2d 281, 288 (6th Cir. 1964), and Michael v. United States, 338 F.2d 219, 221 (6th Cir. 1964); compare Pflugradt v. United States, 310 F.2d 412, 415 (7th Cir. 1962), and J. S. Tyree, Chemist, Inc. v. Thymo Borine Laboratory, 151 F.2d 621, 624 (7th Cir. 1945), with Hill v. Gregory, 241 F.2d 612, 614 (7th Cir.), cert. denied, 354 U.S. 938 (1957), and Central Ry. Signal Co. v. Longden, 194 F.2d 310, 317-18 (7th Cir. 1952). The Eighth Circuit has consistently taken the position that law apphication is a finding of fact, protected by the "unless clearly erroneous" test of Rule 52 (a). E.g., Worthen Bank \& Trust Co. v. Franklin Life Ins. Co., 370 F.2d 97, 100 (8th Cir. 1966). But see St. Louis Umion Trust Co. v. Finnegan, 197 F.2d 565, 568 (8th Cir. 1952). The First and Tenth Circuits also lean strongly in this direction. E.g., Collins v. Commissioner, 216 F.2d 519, 522 (1st Cir. 1954); see Beatrice Foods Co, v. Neosho Valley Cooperative Creamery Ass'n, 297 F.2d 447, 449 (10th Cir. 1961). The Second and Third Circuits have generally taken the opposite position. E.g., United Nations Korean Reconstr. Agency v. Glass Prod. Methods, Inc., 291 F.2d 168, 170 (2d Cir. 1961); Soles v. Franzblau, 352 F.2d 47, 50 (3d Cir. 1965). But see Ruby v. American Airlines, Inc., 329 F.2d 11 (2d Cir. 1964), vacated as moot sub nom. O'Connell v. Manning, 381 U.S. 277 (1965). For cases from the D.C. and Fourth Circuits, see notes 52-57,60 infra and accompanying text.

27 E.g., compare Saturn Oil \& Gas Co. v. Northern Natural Gas Co., 359 F.2d 297 (8th Cir. 1966), with Gulf, C. \& S.F. Ry. v. Coca-Cola Bottling Co., 363 F.2d 465, 467 (5th Cir. 1966). Compare Dixon v. United States, 296 F.2d 556, 558 (8th Cir. 1961), with Plomb Tool Co. v. Sanger, 193 F.2d 260, 264 (9th Cir. 1951), cert. denied, 343 U.S. 919 (1952). Compare John R. Thompson Co. v. Holloway, 366 F.2d 108 (5th Cir. 1966), and Beatrice Foods Co. v. Neosho Valley Cooperative Creamery Ass'n, 297 F.2d 447, 449 (10th Cir. 1961), with Family Circle, Inc. v. Family Circle Associates, Inc., 332 F.2d 534 (3d Cir. 1964), and Fleischmann Distilling Corp. v. Maier Brewing Co., 314 F.2d 149, 152 (9th Cir.), cert. denied, 374 U.S. 830 (1963). See also notes 40-72, 131-39 infra and accompanying text. 
recognition of law application-in the nonjury as well as the jury caseas neither pure law nor pure fact. The weight to be accorded the trial judge's views should depend not on meaningless terminology but on the relative strengths and weaknesses of a trial and appellate court.

The problem can be illuminated by examining cases concerning the scope of review to be accorded a trial judge's apphication of a particular legal standard. The law of negligence furnishes sucll a standard in the reasonably prudent man test applied by the trial court to undisputed or established facts.

II

REASONABLE MAN: THE NEGLIGENCE CASES

\section{A. The Prevailing Approach}

In jury cases courts agree that where reasonable men can differ jurors rather than the trial judge should decide whether a given set of historical facts constitutes negligence. ${ }^{28}$ In orthodox phraseology it is a question of fact for the jury and not a question of law for the trial court whether a party acted as a reasonably prudent man would act under like circumstances. ${ }^{29}$

In the nonjury context, most courts have assumed that the trial judge, as the "trier of fact," occupies the same position as a jury, and that accordingly, his ultimate conclusion as to negligence should be treated as a "finding of fact." The trial judge's decision therefore enjoys a degree of finality comparable to that of a jury verdict. ${ }^{30}$ The jury's conclusion on neghigence will be overturned only if reasonable men could not have reached the same result. ${ }^{31}$ In a case governed by Rule 52 (a) or its equivalent, an appellate court will uphold the judge's "finding of fact" unless a clear error has been committed. In a case not so governed, it will uphold his conclusion if it represents a rational inference from the evidence. ${ }^{32}$ In reality these tests are probably substantially identical in impact. ${ }^{33}$ What-

28 See Weiner, supra note 1 , at 1876-77.

29 Id. at 1877 . A court may refuse to permit the issue to go to the jury if either appellate case law or a legislative pronouncement is deemed to have established how a reasonable man would act under the very circumstances in question. Id. at 1883-86.

30 An 1865 federal statute, which remained in effect until the adoption of the Federal Rules in 1938, provided that, when a jury trial had been waived, the trial court's factual findings should be given the same weight as a jury verdict. Act of March 3,1865, ch. 86, \& 4, 13 Stat. 501.

31 Weiner, supra note 1 , at 1882-83.

32 Text accompanying notes 36,39 infra. Sometimes the test is said to be whether the trial court's determination is supported by any substantial evidence. E.g, Iden v. Zeeman Clothing Co., 50 Cal. App. 2d 111, 114, 122 P.2d 626, 627 (1942).

83 In interpreting Rule 52(a), one court has stated that "we may not substitute our -judgment if conflicting inferences may be drawn-from the established facts .by rẹasonable men, and the inferences drawn by the trial court are those which could have been drawn by 
ever the phraseology of the governing criterion, the appellate court will reverse only if it is deeply disturbed by the result reached below.

A Cahifornia case, Cletro v. Valley Stores, Incorporated, ${ }^{34}$ illustrates this approach. The plaintiff sued a store owner for injuries caused by an exploding soft drink bottle, which was displayed near the aisle and was knocked over by a young child. After a trial without a jury, the court found for the defendant. The appellate court affirmed, rejecting the plaintiff's contention that the finding of no neghigence "is not supported by any substantial evidence." ${ }^{355}$ The court reasoned:

[W] hether [defendant] met this standard [of ordinary care] is a question of fact and not of law. Even when there is no conflict in the evidence, if different conclusions on the subject can rationally be drawn from the evidence the question of neghigence is one of fact. ${ }^{\mathbf{3 6}}$

The court cited as authority for this proposition a case where a jury's conclusion as to neghigence was upheld on appeal..$^{37}$ Although the court did not mention that the cited case concerned a jury trial, it undoubtedly would have thought the precedent equally applicable to a determination by a jury or a judge.

Similarly, in McIntyre v. Doe $\mathcal{E} R o e,{ }^{38}$ where the facts were also undisputed, a trial judge's determination of lack of neghigence was affirmed on appeal with the following comments:

[T] he problem for decision in this case was one of fact. . .

... [T] he trial judge determined that defendants were not negh-

gent. Even if this Court were of the opinion that that determination was wrong, it would not have the power to substitute its deductions for those of the trial court.

reasonable men." Lundgren v. Freeman, 307 F.2d 104, 113 (9th Cir. 1962). See also cases cited in C. WRIGHT, supra note $24, \S 96$, at $377 \mathrm{nn} \cdot 39-41$.

It bas been suggested that an appellate court may feel that "a finding below is unquestionably wrong, even if a reasonable man might have made it." Stern, supra note 24 , at 89. It has also been suggested that a finding may be clearly erroneous, even though supported by substantial evidence. 2B W. Barron \& A. Holtzoff, Federal Practice and Procedure § 1135 (C. Wright ed. 1961). In Jersey Ins. Co. v. Heffron, 242 F.2d 136, 139 (4th Cir. 1957), the court observed that it "has broader powers in reviewing a District Judge's findings of fact than in reviewing the findings of a jury," but went on to say that "it will not disturb his findings merely because it may doubt their correctness." Accord, United States v. Aluminum Co. of America, 148 F.2d 416, 433 (2d Cir. 1945).

It is debatable whether, as a practical matter, these differences in terminology are very meaningful. What is significant is that the cases declaring a "finding of fact" by a trial judge to be clearly erroneous are relatively rare, when compared with the plethora of cases where such a finding has been held not clearly erroneous.

34 117 Cal. App. 2d 709, 256 P.2d 616 (1953).

$85 I d$. at 711,256 P.2d at 618.

${ }^{38} I d$. at 712,256 P.2d at 618 .

37 Thompson v. B. F. Goodrich Co., 48 Cal. App. 2d 723, 120 P.2d 693 (1941).

38125 Cal. App. 2d 285, 270 P.2d 21 (1954). 
... [W] [Wen opposing inferences may reasonably be drawn from the facts in a case, the findings of the trial court will not be set aside. ${ }^{30}$

In the federal courts, the Eighth Circuit has consistently taken a similar position:

Even though the facts are undisputed, the ultimate question as to whether or not negligence may be inferred therefrom may still remain a question of fact for determination by the jury if the case is tried to a jury, or by the court if the case is tried to the court. The court here... determined as a matter of fact that the defendant was not guilty of neghigence.

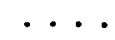

... We cannot say from this record that the findings are clearly erroneous. . . . 40

The court here expressly analogized the position of the trial judge to that of a jury.

\section{B. The Second Circuit View}

The Second Circuit, however, has taken a strikingly different approach. In a 1943 case, ${ }^{41}$ where the facts were undisputed, the court reviewed a trial judge's determination that the defendant was not negligent. Rejecting the contention that the "unless clearly erroneous" test was

39 Id. at 287, 270 P.2d at 22-23 (emphasis added). For other Cahifornia cases upholding a trial judge's conclusion on negligence on the ground that a question of fact was presented for the trier of fact, see, e.g., Hamilton v. Pacific Elec. Ry., 12 Cal. 2d 598, 86 P.2d 829 (1939) (facts undisputed; court quotes from cases discussing deference to be paid verdict of jury); Rice v. Southern Pac. Co., 247 A.C.A. 817, 55 Cal. Rptr. 840 (1967) (court relies on jury cases); Wexler v. City of Los Angeles, 110 Cal. App. 2d 740, 746, 243 P.2d 868, 871 (1952) (court cites jury case); Ebert v. Tide Water Associated Oil Co., 54 Cal. App. 2d 497, 501, 129 P.2d 135, 137 (1942) (court cites two jury cases); Iden v. Zeeman Clothing Co., 50 Cal. App. 2d 111, 113-14, 122 P.2d 626, 627 (1942) (court cites four jury cases); Whitmeyer v. Southern Pac. Co., 102 Cal. App. 199, 282 P. 1005 (1929) (court cites seven jury cases, and uses "jury" and "trial court" interchangeably). See also Umited States v. Fotopulos, 180 F.2d 631, 635-36 (9th Cir. 1950). But see note 68 infra. For cases from other jurisdictions, see, e.g., Allen v. Benjamin Motors, Inc., 108 Conn. 732, 142 A. 405 (1928) (conclusion of trial court on neghigence conclusive, as question was one "of mixed law and fact"); Jung v. Dixie Greyhound Limes, Inc., 329 Ill. App. 361, 68 N.E.2d 627 (1946); Beardsley v. Hobbs, 239 Iowa 1332, 34 N.W.2d 916 (1948) ; Fiusky Hi-Power, Inc. v. Salt Creek Freightways, 366 P.2d 1003 (Wyo. 1961).

40 Merritt v. Interstate Transit Lines, 171 F.2d 605, 608-09 (8th Cir. 1948). Accord, Chicago \& N.W. Ry. v. Minnesota Transfer Ry., 371 F.2d 129, 131 (8th Cir. 1967); Lewis v. Super Valu Stores, Inc., 364 F.2d 555 (8th Cir. 1966); Colorado Milling \& Elevator Co. v. Terminal R.R. Ass'n, 350 F.2d 273, 277 (8th Cir. 1965), cert. denied, 382 U.S. 989 (1966); Ashley v. United States, 326 F.2d 499 (8th Cir. 1964); United States v. Stoppelmann, 266 F.2d 13 (8th Cir. 1959); Fix Fuel \& Material Co. v. Wabash R.R., 243 F.2d 110, 114 (8th Cir. 1957) ; Maryland Cas. Co. v. Independent Metal Prods. Co., 203 F.2d 838, 842 (8th Cir. 1953) ; Peterson v. Denevan, 177 F.2d 411, 412 (8th Cir. 1949).

41 Sidney Blumenthal \& Co. v. Atlantic Coast Line R.R., 139 F.2d 288 (2d Cir. 1943), cert. denied, 321 U.S. 795 (1944). 
applicable, Judge Learned Hand reversed, stating that the "proper standard of care," although a "question of fact" for a jury, should not be a question of fact for the judge. ${ }^{42}$ In three prior admiralty appeals, Judge Hand had summarily declared that the degree of vigilance required of one accused of negligence was a question of law. ${ }^{43}$ In four subsequent admiralty opinions, Judge Hand reiterated that in a nonjury case the issue of negligence was freely reviewable by appellate judges. ${ }^{44}$ In one of those opinions he declared that the choices made in resolving this issue "are the very stuff of law, and as to them appellate courts have no reason to defer to the decisions of the courts of first instance."45 Judge Frank, writing for the court in two admiralty cases, endorsed the Hand position, ${ }^{46}$ and so did Judge Clark in another admiralty appeal.47 In a 1956 opinion written by Judge Swan, the doctrine was applied in a private damage suit brought under the federal securities laws, presenting the question whether defendants had exercised "reasonable diligence."

42 Id. at 290.

43 The Ira S. Bushey, Inc., 120 F.2d 1010 (2d Cir. 1941); Ford Motor Co. v. Manhattan Lighterage Corp., 97 F.2d 577, 579 (2d Cir. 1938); The C.W. Patterson, 70 F.2d 712 (2d Cir. 1934). In all three cases the trial judge was reversed, the Second Circuit holding in one of the cases that there was negligence, and in the other two that there was not. While the Bushey decision is designated as per curian, Judge Hand was on the panel, and the opinion uninistakably bears his imprint.

Although the Admiralty Rules had no counterpart to Federal Rule of Civil Procedure 52 (a), the courts of appeals had generally held that the "unless clearly erroneous" standard, or some equivalent restraint, would nevertheless be applied to the review of "findings of fact" in admiralty appeals. See Judge Hand's opinion in Petterson Lighterage \& Towing Corp. v. New York Cent. R.R., 126 F.2d 992, 995 (2d Cir. 1942), and cases cited in appendix thereto. Cf. Aduniralty R. 46 1/2, discussed in McAllister v. United States 384 U.S. 19 (1954). This position was specifically approved by the Supreme Court in $i d$. at 20. Since 1966, admiralty appeals have been governed by the Federal Rules of Civil Procedure and are thus expressly subject to Rule $52(a)$.

44 Lynch v. Agwilines, Inc., 184 F.2d 826, 828 (2d Cir. 1950), modified on other grounds, 186 F.2d 796 (2d Cir. 1951); Guerrini v. United States, 167 F.2d 352, 356 (2d Cir.), cert. denied, 335 U.S. 843 (1948); Great Atl. \& Pac. Tea Co. v. Brasileiro, 159 F.2d 661, 665 (2d Cir.), cert. denied, 331 U.S. 836 (1947); Barbarino v. Stanhope S.S. Co., 151 F.2d 553, 555 (2d Cir. 1945). See also the per curiam opinion of a panel which included Judge Hand, Continental Ins. Co. v. United States, 195 F.2d 527, 528 (2d Cir. 1952).

45 Barbarino v. Stanhope S.S. Co., 151 F.2d 553, 555 (2d Cir. 1945). See also Great Atl. \& Pac. Co. v. Brasileiro, 159 F.2d 661, 665 (2d Cir.), cert. denied, 331 U.S. 836 (1947) (determination of negligence "demands the setting of a standard, a norm, an imperative, which is the usual hallnark of a jural act. Certainly such a decision is not bike a decision of fact uncolored by any element of choice or fiat.")

46 New York, N.H. \& H.R.R. v. Gray, 240 F.2d 460, 465 (2d Cir.), cert. denied, 353 U.S. 966 (1957); Kreste v. United States, 158 F.2d 575, 577 (2d Cir. 1946). See also dictun in Judge Frank's opinion in a Federal Tort Clains Act case, Johnson v. United States, 168 F.2d 886, 887 (2d Cir. 1948).

47 Verbeeck v. Black Diamond S.S. Corp., 269 F.2d 68, 70 (2d Cir.), modified on other gronunds, 273 F.2d 61 (2d Cir. 1959), cert. denied, 361 U.S. 934 (1960).

48 Dale v. Rosenfeld, 229 F.2d 855, 858 (2d Cir. 1956). 
More recently, Judge Friendly has spoken for the Second Circuit in a series of decisions, both in civil actions and admiralty, holding that "a judge's determination of negligence, as distinguished from the evidentiary facts leading to it, is a conclusion of law freely reviewable on appeal. ..." In a 1966 opinion, Judge Friendly suggested a somewhat different approach to the problem, noting that "the imperatives of F.R. Civ. P. 52(a) and its analogues are avoided whenever the issue is not one of 'fact'; there is no necessity for going further and endeavoring to establish that it is one of 'law' in the usual meaning of that term." 50 Judge Friendly thus recogmized that although the "application of a legal standard" like negligence may not neatly fit the "conclusion of law" category, it is not in any event subject to the "unless clearly erroneous" mandate.

The Fourth Circuit specifically endorsed the Second Circuit view in Hicks v. United States, ${ }^{62}$ a 1966 Federal Tort Claims Act case. Judge Sobeloff held that the "unless clearly erroneous" test was inapplicable, because "the ultimate conclusion to be drawn from the basic facts, i.e., the existence or absence of negligence, is actually a question of law." helpful than this categorical classification is the court's recognition that the determination of negligence involves "application [of a legal standard] to the evidentiary facts as established." "T4 The court's reference to the Second Circuit position as "the general rule" may at least settle the issue for the Fourth Circuit ${ }^{56}$ whose prior decisions

49 Romero v. Garcia \& Diaz, Inc., 286 F.2d 347, 355 (2d Cir.), cert. denied, 365 U.S. 869 (1961); accord, Mamiye Bros. v. Barber S.S. Lines, Inc., 360 F.2d 774, 776-78 (2d Cir.), cert. denied, 385 U.S. 835 (1966); Gediman v. Anheuser Busch, Inc., 299 F.2d 537, 547 (2d Cir. 1962); cf. Ruby v. American Airlines, Inc., 329 F.2d 11, 23 (2d Cir. 1964) (dissenting opinion), vacated as moot sub nom. O'Connell v. Manning, 381 U.S. 277 (1965); Ellernuan Lines, Ltd. v. The President Harding, 288 F.2d 288, 291-92 (2d Cir. 1961). Other Second Circuit judges have followed the Hand-Friendly approach in writing opinions for the court. Skibs A/S Dalfonn v. S/T Alabama, 373 F.2d 101, 106 (2d Cir. 1967) (Anderson, J.); Castro v. Moore-McCormack Lines, Inc., 325 F.2d 72, 75 (2d Cir. 1963) (Medina, J.); Kane v. Branch Motor Express Co., 290 F.2d 503, 506-07 (2d Cir. 1961) (Smith, J.). But cf. Hutton Co. v. Arrow Builders Supply Corp., 371 F.2d 944, 948 (2d Cir. 1967); Radovich v. Cunard S.S. Co., 364 F.2d 149 (2d Cir. 1966); Gill v. United States, 184 F.2d 49, 54 (2d Cir. 1950).

50 In re Hygrade Envelope Corp., 366 F.2d 584, 588 (2d Cir. 1966).

51 Id.

52368 F.2d 626 (4th Cir. 1966).

$53 \mathrm{Id}$. at 631 . The historical facts in Hicks were undisputed.

$54 I d$. The court also noted that "the question before us is not one of fact in the usual sense. ..."Id.

$55 I d$.

56 But cf. Banko v. Continental Motors Corp., 373 F.2d 314, 315 (4th Cir. 1966). See also Northern Assurance Co. v. Spencer, 373 F.2d 35, 37 (4th Cir. 1966) ("unless clearly erroneous" test applied to finding that plaintiff "reasonably assumed" employee of defendant had authority to accept information). In Harris v. United States, 370 F.2d 887, 894-95 (4th Cir. 1966), a tax case, the court, citing Hicks, held the decision below freely reviewable, since "based entirely upon factual stipulation and documentary evidence." 
are in sharp conflict regarding the scope of review to be accorded a judge's conclusion as to neghigence. ${ }^{\mathbf{5 7}}$

In a recent diversity case, the Third Circuit unqualifiedly accepted the Second Circuit view, ${ }^{58}$ ignoring its own prior decisions suggesting the opposite result..$^{50}$ Judge Bazelon of the D.C. Circuit has also alhed himself with the Second Circuit, rejecting the position of two colleagues that the "unless clearly erroneous" standard should govern "ultimate determinations, such as negligence vel non." Although its prior opinions point both ways, ${ }^{01}$ the Fifth Circuit has favorably cited one of the leading Second Circuit cases. ${ }^{62}$

\section{The Ninth Circuit View}

Only the Ninth Circuit has both expressly recognized and rejected the Second Circuit view;" it has flatly declared, "We are committed to the proposition that a finding as to negligence . . . is one of fact, not to be upset by us unless clearly erroneous." ${ }^{24}$ This doctrine has been repeatedly applied in both admiralty appeals ${ }^{65}$ and civil actions tried without a jury. ${ }^{60}$

57 Compare Olah v. S.S. Jaladurga, 343 F.2d 457, 458-59 (4th Cir. 1965), and Bonnewell v. United States, 170 F.2d 411, 412 (4th Cir. 1948) (consistent with Hicks), with Otis Elevator Co. v. Kass Realty Co., 353 F.2d 674 (4th Cir. 1965) (per curiam), and Darter v. Greenville Community Hotel Corp., 301 F.2d 70, 72-73, 77 (4th Cir. 1962) (not consistent with Hicks).

58 Nolan v. Sullivan, 372 F.2d 776, 778 (3d Cir. 1967).

50 Wiseman v. United States, 327 F.2d 701, 707 (3d Cir. 1964); Pennsylvania R.R. v. S.S. Marie Leonhardt, 320 F.2d 262, 264 (3d Cir. 1963); Jackson v. United States, 196 F.2d 725, 726 (3d Cir. 1952).

${ }^{60}$ Socash v. Addison Crane Co., 346 F.2d 420, 422 (D.C. Cir. 1965) (concurring opinion).

61 Compare Sisung v. Tiger Pass Shipyard Co., 303 F.2d 318, 322 (5th Cir. 1962) (negligence case; court implies "unless clearly erroneous" test inapplicable to "conclusions requiring the apphication of legal standards"), with Herrin Motor Lines v. Jarvis, 156 F.2d 276, 278 (5th Cir. 1946) (negligence case; "unless clcarly erroneous" test applicable to "Iegal conclusions applied to ... facts"); cf. United States v. Hill Lines, Inc., 175 F.2d 770 (5th Cir. 1949).

82 Smith v. M/V Gisna, 362 F.2d 164, 166 (5th Cir. 1966), citing Mamiye Bros. v. Barber S.S. Lines, Inc., 360 F.2d 774 (2d Cir. 1966). But see Louisiana \& A. Ry. v. Fireman's Fund Ins. Co., 380 F.2d 541, 543 (5th Cir. 1967).

63 Pacific Tow Boat Co. v. States Marine Corp., 276 F.2d 745, 752 (9th Cir. 1960). The Eighth Circuit cases cited in note 40 supra make no reference whatever to the Second Circuit decisions.

84 Ramos v. Matson Navigation Co., 316 F.2d 128, 131 (9th Cir. 1963).

65 Cases cited notes 63-64 supra; Walston v. Lambertsen, 349 F.2d 660, 663 (9th Cir. 1965), cert. denied, 382 U.S. 980 (1966); Shaver Transp. Co. v. Alaska Freight Lines, Inc., 315 F.2d 97, 99-100 (9th Cir. 1963) ;'Lind v. American Trading \& Prod. Corp., 294 F.2d 342, 346 (9th Cir. 1961); Admiral Towing Co. v. Woolen, 290 F.2d 641, 646 (9th Cir. 1961); Albina Engine \& Mach. Works, Inc. v. American Mail Line, Ltd., 263 F.2d 311, 314 (9th Cir. 1959).

66 Townsend v. Benavente, 339 F.2d 421, 422 (9th Cir. 1964); Hampton v. Gebhardt's Chili Powder Co., 294 F.2d 172, 174 (9th Cir. 1961) ; Yellowstone Pipe Line Co. v. Kuczynski, 283 F.2d 415, 418-19 (9th Cir. 1960); United States v. Fotopulos, 180 F.2d 631, 634-36 (9th Cir. 1950). Noting the conflict with the Second Circuit, one Ninth Circuit opinion intimated 
Yet, in a 1964 Ninth Circuit opinion, the court stated, without citation of authority, that expressions such as "active" and "passive" negligence "are but legal conclusions or inferences, drawn from all the facts and circumstances of a particular case," and that, "In these circumstances, we are not bound by himitations of Rule 52(a)."67 Surely this reasoning dictates that the inference whether a party was negligent at all, "drawn from all the facts and circumstances," should also fall outside the scope of the rule. $^{68}$

\section{The Uncommitted Federal Courts}

The remaining courts of appeals have not squarely faced the issue, although decisions of the Sixth, ${ }^{69}$ Seventh, ${ }^{70}$ and Tenth Circuits ${ }^{71}$ may be construed as supporting the position of the Eighth and Ninth Circuits. ${ }^{72}$ Of course, the issue of the applicable standard of review arises only when the appellate court disagrees with the trial judge on the negligence issue. Otherwise, the court may comfortably resolve the case by repeating the "unless clearly erroneous" maxim. This phenomenon may explain why

that its own position should be reconsidered. Gypsum Carriers, Inc. v. Handelsman, 307 F.2d 525, 528 (9th Cir. 1962). However, subsequent cases did not take the hint. See cases cited supra and in notes 64-65 supra.

67 United Air Lines, Inc. v. Wiener, 335 F.2d 379, 401-02 (9th Cir. 1964).

68 In a recent California case, the court held that whether a party's negligence sbould be characterized as "passive," in which case a right of indemnity would exist against a party guilty of "active" negligence, should not be deemed a "question of fact" in a nonjury case, since "that view would confine the reviewing court to an inquiry into the presence of substantial evidence to justify the award." Aerojet Gen. Corp. v. D. Zelinsky \& Sons, 249 A.C.A. 688, 694, 57 Cal. Rptr. 701, 705 (1967). "Once the physical events are clear or established by findings, the decision for or against indemnity involves cbaracterization of the facts rather than truth finding." Id. The court noted that it did not want to enter the "thorny thicket" of the law-fact distinction, but concluded that it felt "obligated to review the trial court's application of legal standards to the facts at hand." Id. But cf. Pierce v. Turner, 205 Cal. App. 2d 264, 23 Cal. Rptr. 115 (1962) (judge's conclusion that indemnity was not available described as "one of fact"). Perhaps Justice Leonard Friedman's perceptive opinion in Aerojet will trigger a more profound approach by California courts to the related question of the appropriate scope of review in a nonjury neghigence case.

69 Zurich Ins. Co. v. Fisher Contracting Co., 371 F.2d 513, 515 (6th Cir. 1967); Imperial Oil, Ltd. v. Drlik, 234 F.2d 4, 10 (6th Cir.), cert. denied, 352 U.S. 941 (1956); Blytheville Cotton Oil Co. v. Kurn, 155 F.2d 467, 470 (6th Cir. 1946).

70 Leatherman v. Gateway Transp. Co., 331 F.2d 241, 244 (7th Cir. 1964); Parker v. Heresz, 295 F.2d 731, 735 (7th Cir. 1961).

71 Watts v. Roberts, 282 F.2d 565, 566 (10th Cir. 1960) ; cf. Maragakis v. United States, 172 F.2d 393, 395 (10th Cir. 1949) (dictum).

72 The cases cited in notes 69-71 silpra contain statements indicating that a trial court's finding of neghigence must stand unless clearly erroneous. However, it is not clear whether the decisions are referring to the trial judge's reconstruction of the historical facts, his apphication of the standard of reasonable care to such facts, or both. 
all the courts of appeals have not yet made a clear choice between the competing views.

Nevertheless, the existing conflict among many federal appellate courts on a basic, recurring issue should, and perhaps someday will, be resolved by the Supreme Court. ${ }^{73} \mathrm{It}$ has rendered only one relevant negligence decision, McAllister v. United States, ${ }^{74}$ which can be interpreted as holding that the ultimate determination of negligence is a finding of fact. ${ }^{75}$ Judge Friendly, rejecting this interpretation, ${ }^{76}$ has convincingly argued that the Court was simply applying the "unless clearly erroneous" standard to the trial court's resolution of an historical fact, namely, the actual cause of plaintiff's injury. ${ }^{77}$

${ }^{73} \mathrm{~A}$ related question which the Supreme Court might profitably resolve is whether, in a diversity case, the scope of review to be accorded a trial judge's ultimate determination of negligence is governed by federal or state law. No case has squarely confronted this issue; in Kane v. Branch Motor Express Co., 290 F.2d 503, 506-07 (2d Cir. 1961), and Gediman v. Anheuser Busch, Inc., 299 F.2d 537, 547 (2d Cir. 1962), both diversity cases, the court made no mention of state law, and simply cited and followed the Second Circuit rule. This rule had previously been developed in admiralty and federal question cases, except that Sidney Blumenthal \& Co. v. Atlantic Coast Line R.R., 139 F.2d 288 (2d Cir. 1943), cert. denied, 321 U.S. 795 (1944), appears to have been a diversity case. Another diversity case following the Second Circuit rule, without discussing whether state law should govern, is Nolan v. Sullivan, 372 F.2d 776, 778 (3d Cir. 1967). However, in Yellowstone Pipe Line Co. v. Kuczynski, 283 F.2d 415 (9th Cir. 1960), also a diversity case, the court referred extensively to state court decisions, and assumed that state law governed the scope of review as well as other negligence issues. See also United States v. Fotopulos, 180 F.2d 631 (9th Cir. 1950). Since the question revolves around the interpretation of the phrase "findings of fact" in Rule 52(a), Hanna v. Plummer, 380 U.S. 460 (1965), strongly suggests that state law should be irrelevant. Cf. Byrd v. Blue Ridge Rural Elec. Cooperative, Inc., 356 U.S. 525 (1958), holding that the judge-jury relationship in federal diversity cases should not be governed by state law.

74348 U.S. 19 (1954).

75 See Pacific Tow Boat Co. v. States Marine Corp., 276 F.2d 745, 752 (9th Cir. 1960); Imperial Oil, Ltd. v. Drlik, 234 F.2d 4, 10 (6th Cir.), cert. denied, 352 U.S. 941 (1956); 2A W. Barron \& A. Holtzoff, Federal Practice and Procedore \$ 1137, at 563 (C. Wright ed. 1961); C. Wriger, Handbook of the Law of Federat Courts § 96, at 376 (1963).

76 Mamiye Bros. v. Barber S.S. Limes, Inc., 360 F.2d 774, 777-78 (2d Cir.), cert. denied, 385 U.S. 835 (1966). See also Staring, Appeals in Admiralty Cases, 35 Tur. L. Rev. 7, 50 n.231 (1960).

77 In McAllister, the hbellant claimed that he had contracted polio on board ship because of the respondent's neghigence in permitting inhabitants of the polio-infested Shanghai area to have free access to the ship, despite warnings as to the prevalence of the disease. The Second Circuit reversed a damage award. Without expressly deciding whether permitting the Chinese on board ship was negigence, the court held that, "The libellant has the burden of proving that the respondent's negligence caused the injury sustained, and the proof here that the libellant contracted polio from the Chinese is far from satisfactory." McAllister v. United States, 207 F.2d 952, 954 (2d Cir. 1953). In reversing the Second Circuit, the Supreme Court held that a judgment based on the evidence in the record that the hibellant was contaminated by the Chinese was not clearly erroneous. McAllister v. United States, 348 U.S. 19, 20-23 (1954). On the negligence issue, the court remarked that "there was substantial evidence from which the District Court could and did find that respondent was negligent . . ." Id. at 22 . 


\section{E. A Defense of the Second Circuit View}

For several reasons, the Second Circuit's position is the sounder one. ${ }^{78}$

\section{Absence of Constitutional Restraints}

In a negligence case tried to a jury, the constitutional right to jury trial in a civil case may require that the jury apply the reasonable man standard to the established facts and that its conclusion be respected by the trial judge and appellate courts. ${ }^{79}$ Even if refusal to permit jury determination of this issue would be constitutional, it is inconsistent with the constitutional policy in favor of jury decisions. ${ }^{80}$ When a negligence case is tried to a judge alone, however, no constitutional factors compel deference to the judge's application of the governing legal standard. Thus an appellate court is free to reject a conclusion reached by a judge that it would have felt obligated to accept if reached by a jury. ${ }^{81}$

\section{Relative Competence of Trial and Appellate Courts}

Aside from constitutional considerations, the courts have justified jury determination of negligence on the ground that the jury is more competent to perform this task than the trial judge. ${ }^{82}$ As the Supreme Court once stated in a leading negligence case, members of the jury

sit together, consult, apply their separate experience of the affairs of bife to the facts proven, and draw a unanimous conclusion. The average judgment thus given it is the great effort of the law to obtain. It is assumed that twelve nien know nuore of the common affairs of hife than does one man; that they can draw wiser and safer conclusions from admitted facts thus occurring than can a single judge. ${ }^{83}$

These same reasons forcefully dictate that the decision of a "single judge" regarding the exercise of reasonable care should be freely reviewable by a panel of at least three, and perhaps as many as nine, ${ }^{84}$ appellate judges. Although their conclusion, unlike that of a federal jury, need not be unanimous, ${ }^{85}$ a majority of them, applying "their separate experience of

78 For a contrary view, see $2 \mathrm{~A}$ W. BARRoN \& A. Holtzorf, supra note 75, § 1137, at 563.

79 See Weiner, The Civil Jury Trial and the Law-Fact Distinction, 54 CaLIF. L. REv. 1867, 1889-93 (1966).

89 Id. at 1919-22.

81 Cf. United States v. United States Gypsum Co., 333 U.S. 364, 395 (1948).

82 Weiner, supra note 79, at 1887-88.

83 Sioux City \& Pac. R.R. v. Stout, 84 U.S. (17 Wall.) 657, 664 (1874).

84 In addition to the Supreme Court of the Umited States, the Supreme Courts of Iowa, Oklahoma and Texas have nine members who normally sit en banc. IOWA CODE ANN. \& 684.1 (1946); OkIa. Stat. ANv. tit. 20, \& 1 (1962); Tex. Const. art. 5, § 2.

85 Note, however, that in Cahifornia agreement of only three-fourths of the jurors is necessary for a verdict in a civil case. CAL. Code Crv. Pro. $\$ 618$ (West 1955). In New York, five-sixths of the jurors must agree. N.X. Crv. Prac. § 4113(a) (McKinney 1963). 
the affairs of life to the facts proven," must agree whether or not to infer negligence. Thus, as in jury cases, the parties will receive the benefit of a collective judgment on the negligence issue. ${ }^{86}$

Taking a cautious view of the propriety of directed verdicts in negligence cases tried to juries, appellate courts have warned, "Our ideas as to what would be proper care vary according to temperament, knowledge, and experience. A party should not be held to the peculiar notions of the judge as to what would be ordinary care." ${ }^{\prime 87}$ Curiously, most courts have failed to apply these observations to the nonjury trial. Using orthodox terminology, it makes sense to label the reasonable man standard a "question of fact" in the jury case, but a "question of law" in the nonjury case. In the nonjury negligence case, the appellate court, not the trial judge, should be analogized to the jury. ${ }^{88}$ Accordingly, it should be free to decide the negligence issue without being sliackled by the opinion of the trial judge. Deference should of course be paid to the trial court's reconstruction of disputed historical facts. Here the trial judge has a significant advantage over the appellate court; having observed the witnesses testifying, he is in a far better position to gauge credibility. But once the facts have been found without clear error, the group of judges on the appellate court is better qualified to decide the issue of negligence than is the trial judge acting alone, according to the teaching of jury cases.

\section{Need for Uniformity}

The ultimate determination of negligence should also be freely reviewable in the nonjury setting to achieve uniform results. To focus on an example previously explored in the jury context, ${ }^{88}$ assume that two

${ }^{86}$ Cf. Stern, Review of Findings of Administrators, Judges and Juries: A Comparative Analysis, 58 HARv. L. Rev. 70, 113 (1944).

87 Herbert v. Southern Pac. Co., 121 Cal. 227, 229, 53 P. 651 (1898). See also Detroit \& M.R.R. v. Van Steinburg, 17 Mich. 99, 120 (1868) (a judge granting a directed verdict "makes his own opinion of what would be generally regarded as prudence a definite rule of law"); $c f$. Pease v. Sinclair Ref. Co., 104 F.2d 183, 187 (2d Cir. 1939); Tabor v. Continental Baking Co., 110 Ind. App. 633, 647, 38 N.E.2d 257, 262 (1941).

$88 \mathrm{Cf}$. Stern, supra note 86 , at 82 . It is true that, in reaching a collective judgment regarding the standard of care a society should exact of its citizens, the jury may have an advantage over an appellate court, in that its members will be drawn from different occupational groups, and will otherwise represent "a cross-section of the community." See Thiel v. Southern Pac. Co., 328 U.S. 217, 220 (1946). In contrast, it may be contended that the meinbers of an appellate bench are not only all lawyers, but "are drawn froin the saine section of the populace." Stern, supra. Yet, surcly the backgrounds of our appellate judges are, in many cases, quite dissimilar; for exanple, compare Chief Justice Warren of the Supreme Court with Justice Harlan. Moreover, the deliberative process of the jury is more closely approximated by the interchange of ideas among a number of individuals, each with his particular views, than by a decision representing the thought processes of one man.

89 See Weiner, supra note 79, at 1924-25; the hypothetical is based on Sioux City \& Pac. R.R. v. Stout, 84 U.S. (17 Wall.) 657 (1874). 
children are injured while playing on an unguarded, unlocked railroad turntable rotating freely because of a broken latch. Separate actions brought on their behalf are both tried without juries. In one case, the trial judge concludes that the undisputed facts do show negligence on the part of the railroad, while the trial judge in the second case reaches the opposite conclusion. Although neither conclusion is clearly wrong, an appellate court having jurisdiction over both appeals should have the freedom to reverse one and affirm the other, thereby ehminating the unfairness flowing from inconsistent results in identical cases. Of course, an appellate court could not harmonize two conflicting jury decisions, however desirable such uniformity may be, if reasonable men could differ on the negligence issue. Although such inconsistency may be the price required by the "command" or "influence" of constitutional guarantees of jury trial," there is no reason to pay the same price in the nonjury cases. ${ }^{01}$

In the foregoing hypothetical, free review is desirable even if the two identical cases are tried in different jurisdictions, unreviewable by a single appellate court. If one appellate court has reviewed one of the cases, the appellate court in the second jurisdiction should be free to follow that decision, thereby achieving consistency on the appellate level. This desirable result should not be frustrated by compelling the second appellate court to uphold the conclusion of the trial judge, unless it can be classified as a clear mistake..$^{02}$

In an interesting 1936 opinion, ${ }^{93}$ the Cahiornia Supreme Court wrestled with this problem of inconsistent results. An aqueduct owned by the defendant city broke during a rainstorm, causing flood damage to railroad property owned by one plaintiff and chemical deposits owned by another.

00 See Weiner, supra note 79, at 1920, quoting Byrd v. Blue Ridge Elec. Cooperative, Inc., 356 U.S. 525, 537 (1958).

01 In this connection, see Judge Friendly's penetrating comments in writing for the court in Mamiye Bros. v. Barber S.S. Lines, Inc., 360 F.2d 774, 777 (2d Cir.), cert. denied, 385 U.S. 835 (1966). Cf. his opmion for the court in Meyers v. Selznick Co., 373 F.2d 218, 222 n.2 (2d Cir. 1966).

02 Another reason for the Second Circuit position, as developed by Judge Friendly, is that an appellate court cannot know whether the trial judge has applied the correct legal standard to the historical facts, since he does not give himself instructions. Although in negligence cases the general standard is always the well-known reasonable man rule, nevertheless, there are "further specifications of the general standard" wbich enter into the formulation of the particular test to be apphed in any given case. "Save when the trial judge has gone to unusual lengths in his opinion, the only way in which an appellate court can determine whether he correctly apprehended these manifold specifications of the general standard is by reviewing his result, and if that review is to be effective, it must be unimpeded." Mamiye Bros. v. Barber S.S. Lines, Inc., 360 F.2d 774, 776-77 (2d Cir.), cert. denied, 385 U.S. 835 (1966). See also Kane v. Branch Motor Express Co., 290 F.2d 503, 506-07 (2d Cir. 1961); Romero v. Garcia \& Diaz, Inc., 286 F.2d 347, 355-56 (2d Cir.), cert. denied, 365 U.S. 869 (1961).

03 Southern Pac. Co. v. City of Los Angeles, 5 Cal. 2d 545, 55 P.2d 847 (1936). 
Separate actions against the city, each alleging negligence in the construction and maintenance of the aqueduct, were tried without a jury. The trial judge's finding of no negligence in one suit was affirmed by one district court of appeal. ${ }^{94}$ The trial judge's finding of negligence in the second suit was affirmed by a different district court of appeal. ${ }^{95}$ The state supreme court granted a hearing in both cases, in order that they "might be considered and determined together." ${ }^{\prime 96}$

The court harmonized the conflicting decisions, stating:

It would be most anomalous for such decisions to stand, reaching diametrically opposite conclusions as to the legal effect of the same occurrence, where the essential facts are similarly presented, and are in most particulars undisputed. The rule that a reviewing court is bound by the findings of the trial court on conflicting evidence cannot apply to a situation such as this, where two lower courts, dealing with substantially the same evidence, have reached different conclusions of law, on the legal issue of whether from this evidence legal responsibility is imposed by the law upon the defendant. It is within the proper function of this court, upon petition for hearing, to eliminate this confusion, and to determine the legal effect of the evidence in both cases. ${ }^{97}$

The conclusion reached is a sound one. However, if only one plaintiff had been injured, the appellate court would have felt compelled to defer to the trial court's conclusion on neghigence. Free review resulted only because another unrelated plaintiff, suing separately, was injured by the same act. The court should have repudiated the questionable doctrine of limited review of the neghigence issue, instead of carving out an exception to this doctrine in order to solve its immediate dilemma. Since the court classified as a "legal issue" the ultimate determination as to negligence, it opened the door for expanding the scope of review. Significantly, later California decisions have construed the case narrowly, holding that the standard doctrines of reviewability can be modified only when both confiicting judgments are before the appellate court at the same time. ${ }^{98}$ Thus, if the first judgment is not appealed, a California appellate court cannot reverse an inconsistent, but defensible, second judgment simply because it agrees with the conclusion of the first trial judge on the negligence question.

94 Southern Pac. Co. v. City of Los Angeles, 26 P.2d 896 (2d Dist. Ct. App. 1933).

95 Inyo Chem. Co. v. City of Los Angeles, 34 P.2d 165 (4th Dist. Ct. App. 1934).

${ }^{96}$ Southern Pac. Co. v. City of Los Angeles, 5 Cal. 2d 545, 546, 55 P.2d 847, 848 (1936). 97 Id. at 548, 55 P.2d at 849 .

98 E.g., Dillard v. McKnight, 34 Cal. 2d 209, 224, 209 P.2d 387, 397 (1949); Southern Pac. Co. v. Superior Court, 157 Cal. App. 2d 168, 174-77, 320 P.2d 911, 915-17 (1958); Remy v. Exley Produce Express, Inc., 148 Cal. App. 2d 550, 557, 307 P.2d 65, 69 (1957). But cf. Berryman v. Quinlan, 29 Cal. App. 2d 608, 85 P.2d 202 (1938). 


\section{F. Possible Criticisms of the Second Circuit Viere}

\section{Misconstruction of Rule 52(a)}

However sound as a matter of policy, the Second Circuit position of free reviewability might be challenged as an improper construction of Rule 52(a). One might contend that the draftsmen of the rule considered an application of law to fact to be a finding of fact and therefore subject to the "unless clearly erroneous" mandate. To evaluate this assertion, it is necessary to delve briefly into the historical background of Rule 52(a).

In pre-Federal Rule days, the scope of review in federal nonjury cases hinged upon the law-equity dichotomy. Pursuant to statutory command, ${ }^{90}$ reversal in an action at law was justified only if the findings were supported by no substantial evidence. ${ }^{100}$ In contrast, far more sweeping powers of review were exercised in equity cases. It was frequently stated that de novo review of factual determinations was permitted in equity. ${ }^{101}$ In 1912, however, the equity practice of relying on depositions and answers to interrogatories was modified; witnesses were required to testify orally in open court. ${ }^{102}$ Accordingly, many appellate courts recognized that, despite earlier freedom of review in equity, a factual determination dependent on the credibility of witnesses whose demeanor had been observed by the trial judge should stand unless clearly wrong. ${ }^{103}$ If a trial judge's findings were based on the interpretation of documentary evidence, however, or represented "inferences" from undisputed historical facts, then appellate courts, at no disadvantage in making decisions, continued to exercise the traditional free review of equity. ${ }^{104}$

It is against this background that Rule 52(a) must be considered. The Advisory Committee on the Rules of Civil Procedure, appointed by the

${ }^{90} \mathrm{~A}$ statute enacted by Congress in 1865 provided that, when a jury trial had been waived in an action at law, "the finding of a court upon the facts ... shall have the same effect as the verdict of a jury." Act of March 3, 1865, ch. 86, $\S 4,13$ Stat. 501.

100 E.g., McCaughn v. Real Estate Land Title \& Trust Co., 297 U.S. 606 (1936); Orfield, Appellate Procedure in Equity Cases: A Guide for Appeals at Law, 90 U. PA. L. REv. 563, 592-93 (1942).

101 See Lundgren v. Freeman, 307 F.2d 104, 113-14 (9th Cir. 1962) ; 5 J. Moore, FederAx Practice $\llbracket 52.02$ (2d ed. 1966); R. Pound, Appellate Procedure in Civil Cases 298, 300 (1941); Stern, supra note 86, at 79.

102 Equity R. 46, 226 U.S. 661 (1912); see Clark \& Stone, Review of Findings of Fact, 4 U. CEIT. L. REv. 190, 203-04 (1937).

103 Clark \& Stone, supra note 102, at 207-08; Ilsen \& Hone, Federal Appellate Practice As Affected By the New Rules of Civil Procedure, 24 MrNv. L. Rev. 1, 32 (1939); Orfield, supra note 100, at 563, 594; Stern, supra note 86, at 79-80; Note, Rule 52(a): Appellate Reviezv of Findings of Fact Based on Documentary or Undisputed Evidence, 49 VA. L. REv. 506, 510-11 (1963).

104 Clark \& Stone, supra note 102, at 208; Stern, supra note 86, at 113-14, and cases there cited; Note, supra note 103, at 511. But of. Wright, The Doubtful Omniscience of Appellate Courts, 41 MINN. L. Rev. 751, 765-66 (1957). 
Supreme Court, engaged in lengthy debate as to whether to retain the existing schism between review in law and equity cases, or whether to adopt the law standard, or the equity standard, for all cases. ${ }^{105}$ The Advisory Committee's note to Rule 52(a) indicates how this conflict was resolved, by stating that the rule "accords with the decisions on the scope of review in modern federal equity practice." ${ }^{108}$ However, the note also states that the "unless clearly erroneous" restriction "is applicable to all classes of findings in cases tried without a jury whether the finding is of a fact concerning which there is conflict of testimony, or of a fact deduced or inferred from uncontradicted testimony."107 Thus there appears to be a contradiction between the two sentences of the note ${ }^{108}$ since "modern federal equity practice" would have allowed free review of a trial judge's conclusions from undisputed facts. ${ }^{100}$

Even assuming that the second sentence of the note, establishing himited review, takes precedence over the first, ${ }^{110}$ the Second Circuit's free review of law application is not necessarily inconsistent witli the intent of the framers of the rule. For a "fact deduced or inferred from uncontradicted testimony" may refer only to an ultimate conclusion from circumstantial evidence as to actual events and conditions, and not to a determination resulting from the application of a legal standard to evidentiary data. ${ }^{111}$ Sucl an interpretation is admittedly speculative; it is more hikely that, in view of the ambiguity surrounding the word "fact"

105 Advisory Coner. on Rules for Crvil Procedure, Preichmarary Draft of Rules of Crvi. Procedure xiii-xiv, 120-21 (1936). See also Proceedngs of New York Symíposium on FEDERAI RULes 286-88 (American Bar Ass'n 1938); Blume, Reviev of Facts in Non-Jury Cases, 20 J. Ax. JoD. Soc'Y 68 (1936); Chesnut, Analysis of Proposed New Federal Rules of Civil Procedure, 22 A.B.A.J. 533, 540-41 (1936); Clark, Review of Facts Under Proposed Federal Rules, 20 J. Axr. Jov. Soc'y 129 (1936); Clark, Address on Proposed Rules of Civil Procedure, 22 A.B.A.J. 787, 789 (1936); Hearings on the Federal Rules and H.R. 8892 Before the House Comm. on the Judiciary, 75th Cong., 3d Sess., ser. 17, at 121-22 (1938).

106 Advisory Contar. on Rules for CivIl Procedure, Notes to the Rules of Civil Procedure for the District Courts of the UnIted States 46-47 (1938), reprinted in 5 J. Moore, Federal Practice If 52.01[4] (2d ed. 1966).

107 Id. (emphasis added).

108 See Note, supra note 103, at 515-16.

100 See note 104 supra and accompanying text; Irving Bank-Columbia Trust Co. v. Stoddard, 292 F. 815, 821 (1st Cir. 1923) (trial judge's conclusion that agreement "unfair and oppressive" freely reviewable, since "there is no controversy on facts"); Dunn v. Trefry, 260 F. 147, 148 (1st Cir. 1919) (trial judge's conclusion as to "domicile" of party freely reviewable, since "there is no conflict of evidence" and "single question is what inference should be drawn from the facts").

110 William D. Mitchell, Chairman of the Advisory Committee, stated that "this rule applies whether there is a conflict of evidence or whether there is a difference in opimion as to inferences that may be drawn from undisputed evidence. The notes to the rule make that clear." Proceedings of Creverand Institute on Federad Rules 318 (American Bar Ass'n 1938).

111 Cf. Stern, supra note 86, at 114-15. 
in the context of judicial review, the Advisory Committee in 1938 did not specifically focus upon the difference between reconstruction of historical facts and law application.

A proposed change in Rule 52(a), recommended by the Advisory Committee in $1955,{ }^{112}$ sheds further light on the correct interpretation of the rule. The change was motivated by disapproval of a series of decisions holding, according to the Committee, that "where the testimony before the trial court was by deposition or the evidence was documentary, the reviewing court was in as good a position as the trial judge to evaluate it and thus could more easily discover the findings to be clearly erroneous." ${ }^{113}$ The Committee also referred to the extension of this principle "in some decisions to make review substantially de novo, where the testimony below was not oral."114 Such decisions were stated to be contrary to the "language and intent" of Rule 52 (a).$^{115}$ Significantly, the Committee rejected only the cases giving a trial judge's determination of what happened less weight when based on written data than when based on oral evidence. It did not mention the cases holding in effect that law application-characterization of historical facts in terms of the controlling law-fell outside the ambit of Rule 52 (a). ${ }^{116}$ Althougli the Supreme Court refused to amend the rule in the manner suggested, the significance of this refusal is unclear, since the numerous amendments to the rules proposed in 1955 were all rejected by the Court. ${ }^{117}$

Clues to the thinking of Rule 52(a)'s framers have also been furnished by decisions of Judge Cliarles E. Clark, who served as Reporter to the Advisory Committee before and after his elevation to the bench in 1939 . In a 1941 decision, he held a trial judge's conclusion to be freely reviewable, because "the facts here are not in dispute, and the question is there-

112 Advisory Comm. on Rules for Civil Procedure, Report of Proposed Amendments to Rules of Civil Procedure 51-54 (1955), reprinted in 5 J. Moore, Federal Practice If 52.01[6], 52.01 [7] (Supp. 1966). Rule 52(a) reads in relevant part: "Findings of fact shall not be set aside unless clearly erroneous, and due regard shall be given to the opportunity of the trial court to judge the credibility of witnesses." The Advisory Committee recommended that this language be changed to the following: "Findings of fact shall not be set aside unless clearly erroneous. In the application of this primciple regard shall be given to the special opportunity of the trial court to judge of the credibility of those witnesses who appeared personally before it."

113 Id.

114 Id.

115 Id. Professor Moore, a member of the Advisory Committee, disapproved of the proposed change. See 5 J. Moore, Federal Practice If 52.01[8] (Supp. 1966).

116 See, e.g., the following pre-1955 cases: Galena Oaks Corp. v. Scofield, 218 F.2d 217 (5til Cir. 1954); In re Kellet Aircraft Corp., 186 F.2d 197 (3d Cir. 1950); Kubn v. Princess Lida of Thurn \& Taxis, 119 F.2d 704 (3d Cir. 1941); United States v. Anderson, 108 F.2d 475 (7th Cir. 1939), cert. denied, 309 U.S. 688 (1940); cases cited notes 41-46 stupra.

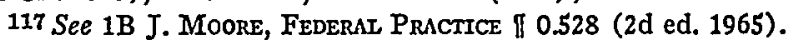


fore not whom to believe, but whether the shower [on a ship] as admittedly constructed was unseaworthy." 118 Twenty years later, lie reiterated that "upon the ascertainment of the facts, deduction of unseaworthiness is a conclusion of law, reviewable as such."119 $\mathrm{He}$ also authored a Second Circuit neghigence opinion, stating unequivocally that "negligence is a conclusion of law which we review." ${ }^{120}$ In a dissenting opinion rendered in 1963, he flatly declared that Rule 52(a) "states the rule as to the status of findings of fact, not a rule as to the apphication or execution of the law to facts found or conceded."121 On other occasions, Judge Clark expressed disapproval of decisions granting free review of a trial court's conclusions as to historical facts, when based upon documentary evidence. $^{122}$

\section{Impact on Efficient Administration of Justice}

A more serious objection than misconstruction of Rule 52(a) may be raised to the Second Circuit position. It may be claimed that free appellate review of a trial judge's ultimate conclusion on negligence is "detrimental to the orderly administration of justice, impairs the confidence of litigants and the public in the decisions of district courts, and multiplies the number of appeals in such cases."123 The prestige of district judges and the alleviation of appellate calendar congestion, while certainly legitimate concerns, do not vitiate the Second Circuit view. The simplest way to enhance the dignity of the district courts and to clear overburdened appellate dockets is to eliminate the right of appeal entirely, at least in

118 Krey v. United States, 123 F.2d 1008, 1010 (2d Cir. 1941).

110 Van Carpals v. The S.S. American Harvester, 297 F.2d 9, 12 (2d Cir. 1961), cert. denied, 369 U.S. 865 (1962).

120 Verbeeck v. Black Diamond S.S. Corp., 269 F.2d 68, 70 (2d Cir.), modified on other grounds, 273 F.2d 61 (2d Cir. 1959), cert. denied, 361 U.S. 934 (1960). See also Judge Clark's opinion in La Touraine Coffee Co. v. Lorrame Coffee Co., 157 F.2d 115, 117 (2d Cir.), cert. denied, 329 U.S. 771 (1946).

121 Sittler v. United States, 316 F.2d 312, 327 (2d Cir. 1963) (dissenting opinion), cert. denied, 376 U.S. 932 (1964). Judge Clark added that "we have a prine question of law and cannot hide behind the gown of the trial judge. Indeed, to attempt to do so is, I submit, to show a lack of judicial candor .... [T] not attempt to evade it." Id. The issue in Sittler was whether denial of a petition for naturalization was justified, because of petitioner's failure to establish his attachment to the principles of the United States Constitution.

122 Heim v. Universal Pictures Co., 154 F.2d 480, 491 (2d Cir. 1946) (concurring opinion) (dictum); Clark, Special Problems in Drafting and Interpreting Procedural Codes and Rules, 3 VAND. L. REv. 493, 505-06 (1950); Clark, Clarifying Amendments to the Federal Rules?, 14 Omo ST. L.J. 241, 247-48 (1953). For a discussion of United States Suprenre Court decisions interpreting Rule 52(a), see notes 161-94 infra and accompanying text.

123 Pendergrass v. New York Life Ins. Co., 181 F.2d 136, 138 (8th Cir. 1950). Cf. Lundgren v. Freeman, 307 F.2d 104, 114 (9th Cir. 1962). See generally Wright, The Doubtful Omniscience of Appellate Courts, 41 MiNs. L. REv. 751 (1957). 
civil cases. This result is precluded by reluctance to grant to a single judge the final authority to adjudicate controversies. ${ }^{124}$ Accordingly, his decisions on "questions of law" have always been freely reviewable by a panel of judges, and his decisions on "questions of fact" have been subject to some review, although often a restricted one. Implicit in this process is the assumption that on some issues the collective wisdom of the judges of the appellate court is more likely to produce a correct result than the unreviewed decision of a trial judge. ${ }^{125}$ The controlling factor is the relative competence of the two tribunals, ${ }^{126}$ and not promotion of trial court dignity and administrative efficiency.

In deciding the advisable scope of review of a trial court's application of the reasonable man standard, one must choose between free review, as for a "question of law," and limited review, as for a "question of fact." If, as previously urged, an appellate court is more qualified than a single trial judge to apply this standard and can achieve the advantages of uniformity by predicating reversal on mere disagreement, then free review is dictated by the very nature of the appellate process.

Moreover, preservation of the dignity of district courts, and free review of law application, are not necessarily inconsistent objectives. The prestige of a district judge is impaired only by reversal. If the court of appeals affirms his decision after free review, his prestige is enhanced to a greater extent than if lis decision is simply found not clearly erroneous. Moreover, affirmances of district court judgments are far more common than reversals, ${ }^{127}$ undoubtedly even in those cases where the decision below is freely reviewed. On the other lrand, if the district judge's conclusion is labelled clearly erroneous, he will suffer a greater loss of prestige than if the appellate court has merely disagreed with him.

Furthermore, the efficiency argument seems somewhat exaggerated. Whether appellate court congestion is aggravated by free review of law application depends in part upon the inhibiting effect on appeals of the task of persuading the reviewing judges that the decision below is clearly erroneous. Optimistic litigants, or hitigants in cases involving substantial sums, may appeal in any event. In other cases appeals may be taken simply to obtain a settlement more favorable than the judgment below.

124 Cf. R. Pound, Appettate Procedure in Civil Cases 3 (1941); J. Rose, Federnt JURISDICTION AND PROCEDURE 574-75 (5th ed. 1938).

125 Cf. C. JoINer, Triats and Appeats 503 (1957).

126 To justify free review, it is not necessary to conclude that appellate judges are "omniscient." Cf. Wright, supra note 123 , at 781 .

127 During the fiscal year ending June 30, 1966 reversals occurred in $24.7 \%$ of private civil cases decided by courts of appeals, and $22.3 \%$ of civil cases to which the United States was a party. 1966 Director of the Admenistrative OFFice of the United States Courts ANr. REP. 149. 
Although meaningful statistical comparisons are virtually impossible, we may wonder whether the Second Circuit view has led to relatively more appeals in neghigence cases than have occurred in the Ninth Circuit. ${ }^{128}$

A court of appeals may be able to act more expeditiously if it need determine only whether the holding below is clearly erroneous. To this extent court congestion will be alleviated. Conscientious appellate judges, however, will devote considerable effort to the task confronting them, even if the scope of review is but a himited one. Moreover, the Second Circuit and its followers have obviously been willing, perhaps anxious, to assume the burden of free review. They may feel that any affront to district courts is outweighed by their own frustration in having to accept a result which, while not clearly erroneous, is wrong.

\section{III}

\section{OTHER QUESTIONS OF REASONABLENESS}

Conclusions about the desirable scope of review in the nonjury neghgence case are relevant to other cases, particularly those which state the controlling principle of law as a general standard of reasonableness. For example, the governing legal criterion may require that a party liave acted

128 During the fiscal year ending June $30,1966,309$ appeals were filed in the Second Circuit and 313 in the Ninth Circuit in civil actions to which the United States was not a party. Id. at 161 . In cases where jurisdiction was founded on diversity of citizenship, 53 appeals were taken in negligence cases in the Second Circuit and 14 in the Ninth Circuit. Id. at 163 . The report does not specify whether these cases were originally tried with or without a jury. Nor does it furnish specific information as to negligence cases where jurisdiction was not founded on diversity of citizenship. The corresponding figures for the fiscal year ended June 30, 1965 are 299 Second Circuit and 298 Ninth Circuit appeals and 20 Second Circuit and 10 Ninth Circuit negligence cases. 1965 Director of tHe AdMInIstrative OfFice of tere Untred States Courts Ann. Rer. 170-71. The prior Annual Reports do not contain information as to the number of negligence cases appealed.

It should be noted, however, that more private "motor vehicle personal injury" and "other personal injury" suits were cominenced in the district courts in the Second Circuit than in those in the Ninth Circuit, as shown by the following table:

\begin{tabular}{ccc}
\hline $\begin{array}{c}\text { Fiscal ycar ending } \\
\text { June 30: }\end{array}$ & $\begin{array}{c}\text { Total of "motor vehicle" and "other" personal injury: } \\
\text { Second Circuit }\end{array}$ & Ninth Circuit \\
\hline 1966 & 1009 & 616 \\
1965 & 1029 & 633 \\
1964 & 1095 & 659 \\
1963 & 1098 & 619 \\
1962 & 1118 & 635 \\
\hline
\end{tabular}

The figures comprising this table are taken from: 1966 DIRECTOR OF THE ADMINISTRATIVE Office of the UNited States Courts ANN. Rep. Table C. 3, at 175 (2d Circuit), 179 (9th - Circuit); $1965^{\prime} i d$. at 183,$187 ; 1964^{-i d}$. at $-221,225 ; 1963$ id. at 201,$205 ; 1962$ id. at 199, 203. Information in the annual reports as to the number of "motor vehicle" and "other" personal injury suits terminated after trial is not broken down by districts or circuits. 
"within a reasonable time" to obtain enforceable rights against another, or that a party charged with malicious prosecution have had "reasonable cause" to institute criminal proceedings against another. ${ }^{129}$ A trial judge's application of a broad standard of reasonableness to undisputed or established data should not be accorded any greater degree of finality than his application of the standard of due care in a negligence case. The factors previously discussed are as pertinent in the former cases as in the latter: The absence of constitutional restrictions on interference with the judgment of the initial trier, the advantages of having a panel of decision makers conclude what is reasonable, and the desirability of giving an appellate court a free hand to reconcile indistinguishable cases..$^{130}$

\section{A. Reasonable Cause: The Bankruptcy Cases}

Not surprisingly, appellate decisions regarding the deference to be paid a trial court's ultimate determination of reasonableness reflect the same inconsistency in bankruptcy cases as in negligence cases. The Bankruptcy Act provides that a preference is voidable if the transferee, at the time when the transfer was made, had "reasonable cause" to believe that the debtor was insolvent. ${ }^{131}$ The opinion of the trial judge concerning such reasonable cause has been classified by the Ninth Circuit as a "finding of fact" subject to the protection of the "unless clearly erroneous" rule. ${ }^{132}$ The Second Circuit, though recognizing the Ninth Circuit view, has emphatically reached the opposite position. ${ }^{133}$ Thus, the disagreement between these two circuits parallels that in the negligence sphere. ${ }^{134}$ Cases

129 See Weiner, The Civil Jury Trial and the Law-Fact Distinction, 54 CALIF. L. Rev. $1867,1895-96$ (1966).

130 Cases presenting the question of whether given conduct is reasonable will normally turn upon a unique set of historical facts. Weiner, supra note 129, at 1928. Thus, indistinguishable cases can be expected to arise primarily when two parties have been affected by defendant's single course of conduct, and separate suits are brought on their behalf. See text accompanying notes 89-98 supra.

131 Bankruptcy Act § 60(b), 11 U.S.C. § 96(b) (1964). "A transferee has such reasonable cause when such a state of facts is brought to his notice respecting the affairs and pecuniary condition of the transferor as would lead a prudent business person to the conclusion that the transferor is insolvent. . . . Where the circumstances are such as would incite a man of ordinary prudence to make inquiry, the transferee is chargeable with notice of all facts which a reasonably diligent inquiry would have disclosed." Robinson v. Commercial Bank, 320 F.2d 106, 107-08 (2d Cir. 1963).

132 Snider v. England, 374 F.2d 717, 719-20 (9th Cir. 1967) (noting conflict with Fifth Circuit); Cedar-Comp Materials Co. v. Bumb, 344 F.2d 256, 258-59 (9th Cir. 1965); C. A. Swanson \& Sons Poultry Co. v. Wylie, 237 F.2d 16, 19 (9th Cir. 1956); Norberg v. Ryan, 193 F.2d 407, 409 (9th Cir. 1951); Security-First Nat'l Bank v. Quittner, 176 F.2d 997, 999 (9th Cir. 1949).

133 In re Hygrade Envelope Corp., 366 F.2d 584, 588-90 (2d Cir. 1966) (excellent opinion by Friendly, J.). See also Second Circuit decisions cited in that opimon. 134 See notes 41-51, 63-66 supra and accompanying text. 
in the First, ${ }^{135}$ Eighth $^{136}$ and Tenth $^{137}$ Circuits appear to be in accord with the Ninth Circuit view, ${ }^{138}$ while decisions in the Fifth Circuit ${ }^{139}$ reach the same conclusion as the Second Circuit.

\section{B. Other Second and Ninth Circuit Cases}

As for other questions of reasonableness, the Second Circuit has held that whether a tort plaintiff acted reasonably to mitigate damages is a determination freely reviewable on appeal in a nonjury case. ${ }^{140}$ This result is consistent with its other opinions. More difficult to understand is a Ninth Circuit decision that whether a party had good cause to terminate a distributorship contract is "a conclusion of law, since . . . based at least in part upon the apphication of a legal standard."141 The standard of good cause would seem equivalent to an inquiry whether the terminating party had acted reasonably. In view of the Ninth Circuit opinions in the negligence area, one would have expected the trial court's ruling to be held a finding of fact.

\section{Reasonable Time: The Commercial Cases}

The ultimate conclusion of a trial judge, sitting without a jury, that a party has acted within a reasonable time has been labelled a finding of fact by some of our courts, ${ }^{142}$ but a freely reviewable decision of law by

135 Salter v. Guaranty Trust Co., 237 F.2d 446, 447 (1st Cir. 1956).

136 Bostian v. Levich, 134 F.2d 284, 287 (8th Cir. 1943); Harrison v. Merchants Nat'I Bank, 124 F.2d 871, 874 (8th Cir. 1942).

$137 \mathrm{McD}$ ougal v. Central Union Conference Ass'n, 110 F.2d 939, 942 (10th Cir. 1940).

138 The position that the trial judge's conclusion as to reasonable cause should not normally be disturbed on appeal also is supported in $3 \mathrm{~W}$. ColrIER, BANKRUPTCY $\llbracket 60.54$, at 1072-73 n.4 (14th ed. 1966).

130 International Minerals \& Chem. Corp. v. Moore, 361 F.2d 849, 851 (5th Cir. 1966); Clower v. First State Bank, 343 F.2d 808, 809-10 (5th Cir. 1965) ; Mayo v. Pioneer Bank \& Trust Co., 297 F.2d 392, 395 (5th Cir. 1961) ; cf. Mizell v. Phillips, 240 F.2d 738 (5th Cir. 1957) (question of fact in jury case). See also Shaw v. United States Rubber Co., 361 F.2d 679, 682 (5th Cir. 1966).

140 Ellerman Lines, Ltd. v. The President Harding, 288 F.2d 288, 291-92 (2d Cir. 1961); accord, In re Kellett Aircraft Corp., 186 F.2d 197, 200 (3d Cir. 1950). See also Badhwar v. Colorado Fuel \& Iron Corp., 245 F.2d 903, 908 (2d Cir.) (dissenting opinion of L. Hand, J.), cert. denied, 355 U.S. 862 (1957) (conclusion that contract was reasonable one of law in case tried to judge). A recent Cahifornia decision in a nonjury case is in direct conflict with Ellerman, holding that "the question of whether the injured party has acted reasonably in initigating damages is one of fact." Sackett v. Spindler, 248 A.C.A. 252, 270, 56 Cal. Rptr. 435, 447 (1967). Significantly, Sackett rehies upon a jury case.

141 Kippen v. American Automatic Typewriter Co., 324 F.2d 742, 745 (9th Cir. 1963).

142 E.g., Travelers Ins. Co. v. Peerless Ins. Co., 287 F.2d 742, 746 (9th Cir. 1961); Lyon v. Goss, 19 Cal. 2d 659, 673, 123 P.2d 11, 19 (1942); Marshall \& Co. v. Weisel, 242 Cal. App. 2d 191, 195, 51 Cal. Rptr. 183, 186 (1966) ; Hannan v. Anderson, 15 Colo. App. 433, 436, 62 P. 961, 962 (1900); Belkin v. New York, N.H. \& H.R.R., 109 Conn. 466, 468, 146 A. 846, 847 (1929) ; Johnson v. Kanavos, 296 Mass. 373, 377, 6 N.E.2d 434, 436 (1937); Tinius Olsen Testing Mach. Co. v. Wolf Co., 297 Pa. 153, 157, 146 A. 541, 542 (1929); cf. United States v. 
others. ${ }^{143}$ Cases in the latter category have reached the right result for the wrong reason. They have blindly relied on jury cases erroneously ${ }^{144}$ holding that determination of a reasonable time on the basis of established facts is a question of law. The prior discussion suggests that the issue should be one of "fact" in the jury trial, but one of "law" in the nonjury trial.

\section{Reasonable Cause: The Malicious Prosecution Cases}

In malicious prosecution cases tried to a jury, courts have generally held determination of probable cause to be a question of law. ${ }^{145}$ The theory is that prosecution of suspected criminals will be unwisely deterred if twelve laymen, influenced by the pliglit of the vindicated criminal defendant, are permitted to resolve the probable cause issue. ${ }^{140}$ Such a justification for jury exclusion is unsound. ${ }^{147}$ Assuming, however, that the cases are correctly decided, their rationale is not applicable to a nonjury case. Thus, when reviewing such a case, an appellate court could readily distinguisl the jury cases holding probable cause to be a question of law, and could give the trial court's application of the probable cause standard the same weight as its ultimate determination of any other issue of reasonableness. The courts, however, have indiscriminately relied upon the jury cases, and have held that probable cause in a nonjury case is also a question of law. ${ }^{148}$ Once again, they have reached the correct result of free reviewability for the wrong reason.

One 1955 Model Ford 2-Door Coach, 261 F.2d 125, 128 (5th Cir. 1958) (finding that party acted within reasonable time held to be clearly erroneous).

143 E.g., First Nat'l Bank v. Pipe \& Contractors' Supply Co., 273 F. 105, 108 (2d Cir. 1921); Colorado Woman's College v. Bradford-Robinson Printing Co., 114 Colo. 237, 244, 157 P.2d 612, 615 (1945); Franklin Paint Co. v. Flaherty, 139 Me. 330, 331, 29 A.2d 651, 652 (1943); Powers, Inc. v. Wayside, Inc., 343 Mass. 686, 691, 180 N.E.2d 677, 680 (1962); cf. Hallman v. Safeway Stores, Inc., 368 F.2d 400, 404 (5th Cir. 1966); Trudeau v. Lussier, 123 Vt. 358, 362, 189 A.2d 529, 533 (1963).

144 See discussion in Weiner, supra note 129, at 1902-07 (1966).

145 Id. at 1910-13. Probable cause in malicious prosecution is synonymous with reasonable cause. Id. at 1910 n.214.

146 Id. at 1913-14.

147 Id. at 1914-16.

148 "[W] hat facts, and whether particular facts, constitute probable cause is always a question of law. [citing jury case] The conclusion of the trial court that the defendant acted without probable cause is therefore a conclusion of law which may be reviewed upon appeal." Brodrib v. Doberstein, 107 Conn. 294, 296, 140 A. 483, 484 (1928); accord, e.g., Garfield v. Peoples Fin. \& Thrift Co., 24 Cal. App. 2d 144, 147, 74 P.2d 1061, 1063 (1937); Richter v. Neilson, 11 Cal. App. 2d 503, 512, 54 P.2d 54, 58 (1936); Morris v. Moore, 61 Cal. App. 314, 316, 214 P. 995, 996 (1923); Carpenter v. Ashley, 15 Cal. App. 461, 464, 115 P. 268, 269 (1911) ; Prostick v. Vroom, 129 N.J.L. 465, 467, 29 A.2d 857, 858 (Ct. Err. \& App. 1943), affirming 128 N.JL. 383, 26 A.2d 268 (Sup. Ct. 1942); see Murdock v. Gerth, 65 Cal. App. 2d 170, 179, 150 P.2d 489, 493 (1944). But cf. Grove v. Purity Stores, Ltd., 153 Cal. App. 2d 234, 240-41, 314 P.2d 543, 547 (1957). In a false imprisonment suit, the probable cause issue has been held to be one of law, and the trial judge's conclusion thereon subject to free review. Michel v. Smith, 188 Cal. 199, 206, 205 P. 113, 116 (1922) (relying on two jury cases). 


\section{E. Unreasonable Delay: The Laches Cases}

The issue of laches, that is, whether a party has unreasonably delayed in asserting a right to the prejudice of another, ${ }^{140}$ has been repeatedly classified as a question of fact for the trial judge. ${ }^{150}$ Despite the harmony of the case law, one may question the soundness of the result. Since "persons claiming excuse for delay must show that they exercised the dihgence required of reasonably prudent persons, ${ }^{3151}$ a compelling argument can again be made that a panel of appellate judges is more competent to apply this reasonable man test than is a single trial judge. Cases embracing the Second Circuit rule on the scope of review in a nonjury negligence case support the position that a trial judge's conclusion on the applicability of laches should be freely reviewable. ${ }^{152}$

IV

\section{IAW APPLICATION IN GENERAI}

The preceding discussion, while focusing upon the scope of review of a trial judge's ultimate determination on reasonableness, is also pertinent to other issues of law application. For example, there is no reason why judges of an appellate court should defer to a trial judge's conclusion, drawn from undisputed or established facts, that an employee was acting within the scope of his employment at the time of an accident. ${ }^{153}$ Other

149 E.g., Walter Bledsoe \& Co. v. Elkhorn Land Co., 219 F.2d 556, 559 (6th Cir. 1955); Marshall v. Marshall, 232 Cal. App. 2d 232, 252, 42 Cal. Rptr. 686, 699 (1965).

150 E.g., Boris v. Hamilton Mfg. Co., 253 F.2d 526, 528-29 (7th Cir. 1958) (applying Rule 52(a)); Beckett v. Kaynar Mfg. Co., 49 Cal. 2d 695, 700, 321 P.2d 749, 752 (1958) (applying substantial evidence rule); $D_{a}$ Silva v. Reeves, 215 Cal. App. 2d 172, 175, 30 Cal. Rptr. 81, 83 (1963); Gutknecht v. Paul, 83 Cal. App. 2d 356, 357, 188 P.2d 764 (1948); cf. Burnett v. New York Cent. R.R., 380 U.S. 424, 435 (1965) (question of laches " 'primarily addressed to the discretion of the trial court" "). In Mahar v. Goodspeed, 30 Cal. App. 2d 391, 394,86 P.2d 382, 384 (1939), the court described laches as "a mixed question of law and fact," but held the finding of the trial court "conclusive."

Laches is an equitable defense, and has been held to be unavailable in an action at law. 30A C.J.S. Equity $\S 113$ (1965). Accordingly, the question whether a determination on laches is one of law or fact has arisen only in the context of the nonjury case.

151 Morales v. Moore-McCormack Lines, Inc., 208 F.2d 218, 221 (5th Cir. 1953). See also First Nat'l Bank v. McGuire, 184 F.2d 620, 626 (7th Cir. 1950) (question of laches depends upon whether "plaintiff is chargeable with a want of due diligence in failing to institute proceedings earlier").

152 One may also question why an appellate court should defer to a trial judge's ultimate conclusion as to the "fairness" of challenged conduct. Yet, in Efron v. Kalmanovitz, 249 A.C.A. 209, 214, 57 Cal. Rptr. 248, 251 (1967), the court held that whether a contract was unfair was a question "of fact to be determined by the trial court," and an appellate court "cannot substitute its judgment for that of the trial court." But of. Bolton v. Stillwagon, 410 Pa. 618, 627, 190 A.2d 105, 109 (1963) (finding that party acted in good faith "merely a conclusion of law" and thus freely reviewable).

153 The courts, however, are in disagreement. Compare, e.g., Whitehurst v. Rainbo Baking Co., 70 N.M. 468, 470, 374 P.2d 849, 850 (1962) (freely reviewable conelusion of law), and 
questions turning upon the classification of a person's employment status should also be freely reviewed. ${ }^{154}$ Similarly, a trial court's application of a specific statutory mandate to given data should be accorded broad review. In this latter area, it is especially important that appellate courts have a free hand to reconcile indistinguishable cases. As one court sagaciously noted in reviewing a case arising under a federal statute, "where the facts of two cases are substantially the same, the law should not be applied differently because trial judges have looked at them in a different way." $" 155$

Three cases decided in recent years are particularly relevant to the present inquiry and shed additional light on the optimal role of the appellate court in a nonjury case.

\section{A. Parsons: $A$ Foot in the Door}

Parsons v. Bristol Development Company, ${ }^{156}$ an opinion by Chief Justice Traynor, could serve as the opening wedge for a broad expansion of the scope of appellate review in traditionally restricted areas. The court there reaffirmed the accepted doctrine that an appellate court is not bound by the trial court's construction of a written contract when extrinsic evidence has not been introduced. ${ }^{157}$ Interpretation of such a contract has traditionally been called a "question of law."158 The court went a signifi-

Pate v. Plymouth Mfg. Co., 198 S.C. 159, 162, 17 S.E.2d 146, 147 (1941) (question of law where evidence undisputed), with Bissell v. McElligott, 369 F.2d 115, 119 (8th Cir. 1966) (finding of fact, subject to "unless clearly erroneous" test), and Cragun v. Krossoff, 45 Cal. App. 2d 480, 486, 114 P.2d 431, 434-35 (1941) (appellate court must accept "reasonable deduction" from evidence as question is "ordinarily one of fact"), and Ritclie v. Waller, 63 Conn. 155, 161-62, 28 A. 29, 30-31 (1893) (question of fact for trier).

$154 \mathrm{On}$ this point, also, the courts are in disagreement. Compare McGuire v. United States, 349 F.2d 644, 646 (9th Cir. 1965) (whether person employee or independent contractor question of fact), and Wirtz v. Atlanta Life Ins. Co., 311 F.2d 646, 647-48 (6th Cir. 1963) (whether person "outside salesman" question of fact), and Dixon v. United States, 296 F.2d 556, 558 (8th Cir. 1961) (whether person employee or independent contractor question of fact), with Donaldson Publishing Co. v. Bregman, Vocco \& Conn, Inc., 375 F.2d 639, 641 (2d Cir. 1967) (whether person "employee for hire" freely reviewable), and Taft Broadcasting Co. v. Columbus-Dayton Local, Am. Fed'n of Television \& Radio Artists, 297 F.2d 149, 152 (6th Cir. 1961) (whether person "employee" of company conclusion of law), and Plomb Tool Co. v. Sanger, 193 F.2d 260, 264 (9th Cir. 1951), cert. denied, 343 U.S. 919 (1952) (whether person employee or independent contractor freely reviewable conclusion).

155 Local 6167, UMW v. Jewell Ridge Coal Corp., 145 F.2d 10, 12 (4th Cir. 1944), aff'd, 325 U.S. 161 (1945); see Stern, Review of Findings of Administrators, Judges and Juries: $A$ Comparative Analysis, 58 HaRv. L. REv. 70, 119-20 (1944).

15662 Cal. 2d 861, 402 P.2d 839, 44 Cal. Rptr. 767 (1965).

157 Id. at 865,402 P.2d at 842,44 Cal. Rptr. at 770 .

158 Weiner, supra note 129, at 1930. Actually, interpretation of a written contract entails one of the following processes: (1) A truly "factual" inquiry into actual states of mind at the time the bargain was struck; (2) apphication of a standard of reasonableness, to determine how language should have been interpreted by a party whose actual intent was different from 
cant step further, however, expressly overruling several cases in the process. It held that when undisputed parol evidence has been introducedwith no question of credibility - from which "conflicting inferences" can be drawn, the appellate court "must make an independent determination of the meaning of the contract."159 The court noted that "the very possibility" of such inferences "signalizes the necessity" of the appellate court's "assuming that responsibility." "160

The implications of the case are enormous. For example, if "conflicting inferences" on the issue of negligence can be drawn from established or uncontroverted facts, there is no greater reason for appellate deference to the trial judge than there was in Parsons. "The very possibility" of differing conclusions equally "signalizes the necessity" of an appellate court's "assuming . . . responsibility." The vast and illogical distinction in California between the scope of review in nonjury contract and tort cases exemplifies the inadequacy of the prevalent approach to such questions.

\section{B. Duberstein: A Closing of the Door?}

In contrast to the promise offered by Parsons for California courts, the United States Supreme Court's Duberstein decision ${ }^{161}$ may obstruct free review by federal appellate courts of law apphication in nonjury cases. In Duberstein, and a related case, Stanton ${ }^{162}$ the Court considered whether payments made in a busmess context were nontaxable gifts to the recipients, or taxable income. Duberstein had received an unsolicited gift of a Cadillac from a business associate to whom he had furnished information about potential customers. Although the Tax Court held that the value of the Cadillac was taxable income, ${ }^{163}$ the Sixth Circuit reversed. ${ }^{164}$ Stanton had served for ten years as president of a corporation wliich managed the real estate holdings of Trinity Church of New York City. When he resigned, the directors of the corporation authorized pay-

that of the other contracting party; (3) application of a standard of fairness and justice, to fill the gaps left by the contracting parties, neither of whom considered the issue in question at the time of the contract. Id. at 1930-32. Cf. E. F. Drew \& Co. v. Reinhard, 170 F.2d 679, 684 (2d Cir. 1948).

15962 Cal. 2 d at 865-66 \& n.2, 402 P.2d at $842-43$ \& n.2, 44 Cal. Rptr. at 770-71 \& n.2.

160 Id. at 866 n.2, 402 P.2d at 843 n.2, 44 Cal. Rptr. at 771 n.2. Since the court affirmed the judgment of the trial court, it went out of its way to declare an enlargement in the scope of review.

The Parsons principles have been applied to construction of a will. E.g., Estate of Meyer, 241 Cal. App. 2d 747, 751, 51 Cal. Rptr. 72, 74 (1966).

161 Commissioner v. Duberstein, 363 U.S. 278 (1960).

162 Stanton v. United States, 363 U.S. 278 (1960).

163 Mose Duberstein, 17 CCH Tax Ct. Mem. 16 (1958).

164 Duberstein v. Commissioner, 265 F.2d 28 (6th Cir. 1959). 
ment of a twenty thousand dollar " gratuity" " to him, ostensibly in recognition of loyal and faithful service, and as a token of good will. ${ }^{105} \mathrm{Al}$ though a federal district judge sitting without a jury held that Stanton had received a nontaxable gift, the Second Circuit reversed. ${ }^{100}$

In a cryptic opinion for a badly split Court, ${ }^{107}$ Justice Brennan identified "the transferor's "intention" "as "the most critical consideration" in resolving the gift-versus-income dispute. ${ }^{108}$ The "proper criterion . . . is one that inquires what the basic reason for his conduct was in fact-the dominant reason that explains his action in making the transfer." statutory gift will be inotivated by a "detached and disinterested generosity," as opposed to a payment proceeding from "the constraining force of any moral or legal duty', or from 'the incentive of anticipated benefit' of an economic nature."170

Having laid down these vague guidelines, the Court declared:

Decision of the issue presented in these cases must be based ultimately on the apphication of the fact-finding tribunal's experience with the mainsprings of human conduct to the totality of the facts of each case. The nontechnical nature of the statutory standard, the close relationship of it to the data of practical human experience, and the multiphicity of relevant factual elements, with their various combinations, creating the necessity of ascribing the proper force to each, confirm us in our conclusion that primary weight in this area must be given to the conclusions of the trier of fact. ${ }^{171}$

Stating that "appellate review of determinations in this field must be quite

105363 U.S. at 281-82. There was evidence that Stanton's resignation had been precipitated by his disagreement with the directors over discharging the treasurer of the corporation. Id. at 282-83. The resolution authorizing the payment to him provided for the release of all claims to pension and retirement benefits which had not accrued as of the date of his resignation. Undisputed testimony was presented that there was no enforceable claim to unaccrued benefits, and that the "proviso of the resolution was inserted simply out of an abundance of caution." Id. at 283 .

100 Stanton v. United States, 268 F.2d 727 (2d Cir. 1959).

167 Only four justices unqualifiedly joined in the opinion of the Court.

188363 U.S. at $285-86$.

$109 \mathrm{Id}$. at 286 .

$170 I d$. at 285 . In Duberstein, the Government contended that the taxpayer could not successfully claim receipt of a gift when the transferor had deducted the value of the Cadillac as a business expense. The Court deemed this factor "relevant" but not conclusive, stating that "the taxing statute does not make nondeductibility by the transferor a condition on the 'gift' exclusion ...." Id. at 287. In 1962, after the Duberstein decision, Congress Himited the deductibility of business "gifts" to $\$ 25$ per year for each donee. 76 Stat. 974, now INT. REv. CODE of 1954, $\$ 274$ (b)(1). For purposes of this section, the definition of a "gift" is geared to $\$ 102(a)$, providing that "gross mcome does not include the value of property acquired by gift...."

171363 U.S. at 289. The Court overruled Bogardus v. Commissioner, see 363 U.S. at 28990 n.11, which had held that "the ultimate determination" of gift or income was a freely reviewable "conclusion of law, or at least a determination of a mixed question of law and fact." " 302 U.S. 34, 39 (1937). However, four dissenters in Bogardus thought that a "question of fact" was presented. Id. at 45 . 
restricted,"172 the Court concluded that the classification of the transfer by the trial judge or Tax Court "must stand unless 'clearly erroneous." "173 The Court noted the applicability of Rule 52(a) to "factual mferences from undisputed basic facts, ... as will on many occasions be presented in this area."174 Accordingly, in Duberstein it reversed the Sixth Circuit, upholding the Tax Court decision that the taxpayer had received income. In Stanton, the Court reversed the Second Circuit, remanding the case to the district court for additional findings. After such findings had been supplied, ${ }^{175}$ the Second Circuit affirmed the district court, since it was unable to say that the lower court's conclusion that a gift had been made was clearly erroneous. ${ }^{\mathbf{1 7 6}}$

Although Duberstein has been broadly interpreted by some courts of appeals, ${ }^{177}$ the case is apparently not concerned with law application as

172363 U.S. at 290.

173 Id. at 291. INT. REv. CoDE of 1954, $\$ 7482$ (a), provides for the same scope of review of a Tax Court decision as of a nonjury district court decision.

174363 U.S. at 291. See also United States v. Singer Mfg. Co., 374 U.S. 174, 194 n.9 (1963) (rule applies to "inferences drawn from documents or undisputed facts"); United States v. United States Gypsum Co., 333 U.S. 364, 394 (1948) (same); cf. Graver Tank \& Mfg. Co. v. Linde Air Prods. Co., 339 U.S. 605, 609-10 (1950).

175 Stanton v. United States, 186 F. Supp. 393 (E.D.N.Y. 1960). The district court took no additional evidence.

176 United States v. Stanton, 287 F.2d 876 (2d Cir. 1961). Chief Judge Lumbard, while noting that affirmance was compelled by the Supreme Court's directive that appellate review be limited, was "of the opinion that the contrary inference should lave been drawn from the undisputed basic facts." Id. at 877 .

${ }_{177}$ Duberstein has been cited over two hundred times by courts of appeals in the seven years since the decision. Most of the cases relying on the Duberstein guidelines as to scope of review have been tax cases. E.g., Imbesi v. Commissioner, 361 F.2d 640, 643 (3d Cir. 1966) ("The principle which formerly liad much vitality that a reviewing court is just as competent as the trial tribunal to determine what inferences should be drawn from the findings of fact no longer applies."); Austin v. Commissioner, 298 F.2d 583, 584 (2d Cir. 1962) ("It is contended that this court is free to draw from the undisputed evidentiary facts legal conclusions different from those drawn by the Tax Court. The Supreme Court bas recently ruled against this contention."); Joshel v. Commissioner, 296 F.2d 645, 648 (10th Cir. 1961) (court questions decision below that taxpayer received income rather than gift, but states that, in view of Duberstein, "it is not within our power to change the result"); Commissioner v. Spermacet Whaling \& Shipping Co., 281 F.2d 646, 651 (6th Cir. 1960) (noting that Duberstein settled prior conflict in decisions of circuit as to scope of review of "conclusions . . . drawn from undisputed facts"). In the tax context, Duberstein has been given an expansive reading, the appellate courts concluding that even ultimate determinations as to the reasonableness of given conduct must be accorded restricted review. E.g., Savko Bros. Co. v. Colnmissioner, 338 F.2d 956, 957 (6th Cir. 1964); Miller v. Commissioner, 333 F.2d 400, 403 (8th Cir. 1964); Nemours Corp. v. Commissioner, 325 F.2d 559, 560 (3d Cir. 1963). But see Miller v. Commissioner, 327 F.2d 846, 849 (2d Cir.), cert. denied, 379 U.S. 816 (1964).

Cases in the Sixth, Eighth and Ninth Circuits, not in the tax field, have rehed upon Duberstein to support the position that application of a legal standard to undisputed historical 'facts is subject to the "unless clearly erroneous" restraint. National Bond Fin. Co. v. General Motors Corp., 341 F.2d 1022 (8th Cir. 1965) (whether one corporation instrumentality or alter ego of another); Carr v. American Universal Ins. Co., 341 F.2d 220, 224 (6th Cir. 1965) (whether young person had implied authority to drive an autoinohile); Bale v. Glasgow 
such, but rather with the reconstruction of actual mental events, namely, the thought processes of the transferor at the time that the alleged gift was made. ${ }^{178}$ The Court seems to have proposed a subjective rather than an objective test of intent, the cases before it hinging on the true states of mind of the respective donors. Yet, cognizance must be taken of the Court's comment "that the donor's characterization of his action is not determinative- that there must be an objective inquiry as to whether what is called a gift amounts to it in reality." ${ }^{" 170}$ While the remark is unclear, the Court may simply have meant that the transferor's representations about his own state of mind may be disbelieved on the basis of other evidence. Presumably the Court did not mean that the test is the state of mind of a hypothetical reasonable man in the position of the transferor. ${ }^{180}$

Nevertheless, the Court's remarks on limited review seem applicable, at least by analogy, to the area of law application. The case is thus a possible roadblock to the narrow application of Rule 52(a) which has been advocated. The foundations of the opinion, however, are most shaky. Appellate courts should not defer to a trial judge's "application" of his "experience with the mainsprings of human conduct to the totality of the facts." 181 The combined experience of three appellate judges with the

Tobacco Bd. of Trade, Inc., 339 F.2d 281, 288 (6th Cir. 1964) (whether restraint of trade unreasonable); Michael v. United States, 338 F.2d 219, 221 (6th Cir. 1964) (whether defendant's act was proximate cause of plaintiff's injuries); Shoppers Fair, Inc. v. Sanders Co., 328 F.2d 496, 498-500 (8th Cir. 1964) (whether trade name used by defendant was confusingly similar to that of plaintiff; whether plaintiff's trade name had secondary meaning in specified area); Allstate Ins. Co. v. Cook, 324 F.2d 752, 753-54 (6th Cir. 1963) (whether representations material); Sterling Aluminum Prods., Inc. v. Bohn Aluminum \& Brass Corp., 298 F.2d 538 (6th Cir. 1962) (whether device patentable); Travelers Ins. Co. v. Peerless Ins. Co., 287 F.2d 742, 746 (9th Cir. 1961) (whether action taken within reasonable time); of. Cole v. Neaf, 334 F.2d 326, 329-30 (8th Cir. 1964) (whether defendant in malicious prosecution suit had acted with malice). In a brief and vague per curiam opinion, the Supreme Court suggested the applicability of Duberstein to a nontax case. Dayton Rubber Co. v. Cordovan Associates, Inc., 364 U.S. 299 (1960), discussed in Note, Rule 52(a): Appellate Review of Findings of Fact Based on Documentary or Undisputed Evidence, 49 VA. L. REv. 506, 525-27 (1963). For a tax case in which the Supreme Court rehed on Duberstein, see Rudolph v. United States, 370 U.S. 269 (1962).

178 See Stanton v. United States, 186 F. Supp. 393, 396 (E.D.N.Y. 1960). Judge Friendly interprets Duberstein as applying to "the drawing of factual inferences from circumstantial evidence." In re Hygrade Envelope Corp., 366 F.2d 584, 588 (2d Cir. 1966). Cf. von Clemm v. Smith, 363 F.2d 19, 23 (2d Cir.), cert. denied, 385 U.S. 975 (1966).

170363 U.S. at 286.

180 See Imbesi v. Commissioner, 361 F.2d 640, 645 n.10 (3d Cir. 1966) ("[T]he Supreme Court [in Duberstein] declined . . . to substitute objective tests for the determination of donative intent."). But of. United States v. Kaiser, 363 U.S. 299, 330 (1960) (dissenting opinion of Whittaker, J.) ("It is now estabhished [under Duberstein] that objective intention of the transferor determines whether transfers constitute 'gifts' . . . .").

181 "Varying conceptions regarding the 'mainsprings of human conduct' are derived from a variety of experiences or assumptions about the nature of man, and 'experience with human affairs' is not only diverse but also often drastically conflicting." 363 U.S. at 297 (concurring and dissenting opimion of Frankfurter, J.). 
mainsprings of human conduct represents a more reliable basis of decision making than the "informed experience with human affairs" of a single trial judge. ${ }^{182}$ Again, reference may be made to the jury cases. If it is advantageous for jurors to "apply their separate experience of the affairs of life to the facts proven, and draw a unanimous conclusion,"183 it is equally advantageous for the members of an appellate court to pool their experience, arriving at a solution at least acceptable to a majority of them. ${ }^{184}$ This process would be hampered by a strong presumption in favor of affirmance of the decision below. Moreover, many federal appellate judges have formerly served as trial judges, so their judicial experience with the mainsprings of human conduct on both the trial and appellate levels may be utilized. Although the "statutory standard" with which the Court was concerned is "nontechnical," court is better equipped to apply it.

Moreover, considerations of uniformity militate against the Court's reasoning. Assume that the taxpayer in Stanton and another corporate officer had both been voted gratuities on resigning from their jobs. Assume further that the Commissioner asserted a deficiency against both taxpayers, that Stanton paid and sued for a refund in the district court, and that his colleague did not pay and was subjected to proceedings in the Tax Court. If both appeals were heard by the Second Circuit, that appellate court should have the freedom to reconcile the district court's conclusion of gift and the Tax Court's conclusion of income. However, since neither of these holdings could be found clearly erroneous under $D u b e r-$ stein ${ }^{186}$ the appellate court could only affirm both judgments. Similarly, if the judgment of the district court was affirmed by the Second Circuit, and the appeal from the Tax Court was heard by the Third Circuit, it

The Supreme Court's decision is more objectionable as it relates to Stanton than to Duberstein, since the Tax Court, unlike a district court, is itself comprised of a panel of decision makers.

182363 U.S. at 292. Elsewhere in its opinion, the Court quoted a passage from Welch v. Helvering, 290 U.S. 111, 115 (1933), which "well fits the issue in the cases at bar," namely, that " the standard set up by the statute is not a rule of law; it is rather a way of hife. Life in all its fullness must supply the answer to the riddle." " 363 U.S. at 288 n.9. Three appellate judges are a more appropriate institution to consult "life in all its fullness" than a single trial judge.

183 Sioux City \& Pac. R.R. v. Stout, 84 U.S. (17 Wall.) 657, 664 (1874).

184 Interestingly, the Court decided another "gift versus income" case on the same day that it rendered its opinion in Duberstein and Stanton. In United States v. Kaiser, 363 U.S. 299 (1960), the Court upheld a jury verdict that strike assistance provided by a union to a worker participating in a strike was a nontaxable gift. "The factual inferences to be drawn from the basic facts were here for the jury." Id. at 304. The criticisms in the text of the Duberstein decision clearly do not apply to Kaiser.

185 See text accompanying note 171 supra.

186 See 363 U.S. at 297-98 (concurring and dissenting opinion), where Justice Frankfurter convincingly argues that the Second Circuit's decision in Stanton adverse to the taxpayer should be affirmed. See also note 176 supra. 
should have a free hand to promote consistency by following the Second Circuit.

Uniformity is desirable in cases other than those involving identically situated taxpayers. It may be true that each gift-versus-income dispute is unique because it hinges on the subjective intent of a particular transferor; nonetheless, two such suits may share enough common elements that a finding of gift in one and income in the other would conflict. The grateful businessman giving a "present" to a useful colleague and the employer voluntarily bestowing a benefit on a retiring employee or a widow of a deceased employee are both familiar figures. ${ }^{187}$ Federal appellate courts, including the Supreme Court, should not be deterred by the restrictions of Rule 52(a) from reconciling decisions which they think are inconsistent. ${ }^{188}$ Moreover, some degree of certainty in this gift-income area is inportant to the taxpaying public, ${ }^{180}$ who may plan out-of-court conduct on the basis of predictable tax consequences. ${ }^{100}$ Legal advice may

187 See 363 U.S. at 295-96 (concurring and dissenting opinion). Stanton may be distinguished on its facts, on the ground that the employer was a religious corporation. See Stanton v. United States, 186 F. Supp. 393, 397 (E.D.N.Y. 1960).

188 Since Duberstein and Stanton, there has been a deluge of litigation on the question whether payments by an employer to the widow of a deceased employee are a gift or income. See Klein, An Enigma in the Federal Income Tax: The Meaning of the Word "Gift," 48 MIN. L. Rev. 215, 217-18 (1963); Note, Payments to Widows of Corporate Executives and Employees-Gifts or Income? 49 VA. L. Rev. 74 (1963); Annot., 95 A.I.R.2d 520 (1964). The cases have produced a lodgepodge of inconsistency, prompting one court to remark that "in the gift v. income arena . . . we are steeled to untidy results." United States v. Pixton, 326 F.2d 626, 628 (5th Cir. 1964). See also Fanning v. Conley, 357 F.2d 37, 39 (2d Cir. 1966) ("[T] Court [in Duberstein] comprehended that inconsistent determinations might well result from the case-by-case approach it was advocating."); Carson v. United States, 317 F.2d 370 (Ct. Cl. 1963). Most of the decisions by courts of appeals have affirmed the conclusion reached below, noting the limited scope of review under Duberstein. E.g., Froehlinger v. United States, 331 F.2d 849 (4th Cir. 1964); Evans v. Commissioner, 330 F.2d 518 (6th Cir. 1964); Cronheim's Estate v. Commissioner, 323 F.2d 706 (8th Cir. 1964); Gaugler v. United States, 312 F.2d 681 (2d Cir. 1963); Smith v. Commissioner, 305 F.2d 778 (3d Cir.), cert. denied, 371 U.S. 904 (1962); United States v. Kasynski, 284 F.2d 143 (10th Cir. 1960). The inconsistency problem has been compounded by the Tax Court's tendency to find the payments income, and the tendency of district judges to classify them as gifts. See cases cited in Note, Voluntary Payments to Widows of Corporate Executives: Gifts or Income? 62 Mict. L. Rev. 1216, 1223-24 (1964).

180 Cf. 363 U.S. at 297 (concurring and dissenting opinion); Griswold, Foreword: of Time and Attitudes-Professor Hart and Judge Arnold, 74 HaRv. L. Rev. 81, 88-91 (1960). Concurring in the judgment in United States v. Kaiser, 363 U.S. 299 (1960), a jury case decided the same day as Duberstein, Justice Frankfurter noted his awareness "that tbis disposition of the case does not preclude different juries reaching different conclusions on the same facts." Id. at 317 (concurring opinion). Compare United States v. Kaiser, supra (strike benefits found by jury not to be taxable income), with Woody v. United States, 368 F.2d 668 (9th Cir. 1966) (strike benefits found by jury to be taxable income). In jury cases, inconsistency may be inevitable; in nonjury cases, the problem can and should be alleviated.

$100 \mathrm{Cf}$. Weiner, The Civil Jury Trial and the Law-Fact Distinction, 54 CarrF. I. REv. 1867, 1927 (1966). In Bessenyey v. Commissioner, 379 F.2d 252, 257 (2d Cir. 1967), the court 
be difficult to give if the cases turn upon ad hoc determinations at the trial level which must stand unless clearly erroneous.

The Supreme Court commented in Duberstein that "diversity of result will tend to be lessened somewhat since federal income tax decisions, even those in tribunals of first instance turning upon issues of fact, tend to be reported, and since there may be a natural tendency of professional triers of fact to follow one another's determinations, even as to factual matters." ${ }^{101}$ Although this consideration may lessen inconsistency, ${ }^{102}$ it seems startling that an appellate court must accept, unless clearly erroneous, a trial court's interpretation and application of legal precedents.

In view of the infirmities of Duberstein, it would be regrettable if the case led to an expansive reading of Rule 52(a). The possibility of this long-range effect has been tempered by brief comments in two subsequent Supreme Court decisions. In 1961 the Court, ignoring Duberstein, categorically proclaimed that "our rehance upon the findings of fact does not preclude us from making an independent determination as to the legal conclusions and inferences which should be drawn from them."193 And in a 1966 opinion, the Court laid the groundwork for a severe cutback in the breadth of Rule 52 (a), by identifying as "the rationale behind" the rule "the trial court's customary opportunity to evaluate the demeanor and thus the credibility of the witnesses."194

\section{Lundgren: A Step Backward}

Lundgren v. Freeman, ${ }^{195}$ a decision of the Ninth Circuit, represents the most ambitious elaboration of Duberstein by a court of appeals. Acting solely on documentary evidence, a district court had decreed reformation of a contract based on mutual mistake. In affirming, Judge Duniway

observed that "the mandate of Duberstein ... may have the unfortunate consequence of lessening the predictability peculiarly essential in tax matters."

101363 U.S. at 290.

192 But see note 188 supra, noting that the Tax Court has not paid much attention to the district courts' decisions on gift versus income, and vice versa.

193 United States v. Mississippi Valley Generating Co., 364 U.S. 520, 526 (1961); accord, United States v. E. I. duPont de Nemours \& Co., 353 U.S. 586, 598 n.28 (1957).

194 United States v. General Motors Corp., 384 U.S. 127, 141 n.16 (1966). The Court referred to the case before it as "essentially a "paper case" "which "did not unfold by the testimony of 'live' witnesses." Id. It classifed as outside the scope of Rule 52(a) "the court's ultimate legal conclusion that there was no conspiracy" violating the Sherman Act, which was not a "question ... of 'fact,' but ... of the legal standard required to be applied to the undisputed facts of the case." Id. at 141-42 n.16. In United Artists Television, Inc. v. Fortnightly Corp., 377 F.2d 872, 874 n.2 (2d Cir. 1967), the court interpreted General Motors as holding that the "clearly erroneous" standard was inapplicable, where "the [historical] facts ... are essentially undisputed."

105307 F.2d 104 (9th Cir. 1962). The decision is discussed with approval in 2B W. Barron \& A. Holtzoff, Federal Practice and Procedure § 1132 (C. Wriglit ed. Supp. 1966); 41 TEXAS L. REv. 935 (1963). 
took the opportunity to explore at length the scope of review which should be accorded holdings of a lower court. As in Duberstein, the issue before the appellate court was not one of law application but of ascertaining mental events-the actual states of mind of the contracting parties at the time of the agreement. Such a determination could meaningfully be classified as a "finding of fact," that is, a reconstruction of an historic occurrence. Approaching the problem from a broader perspective, the court noted the conflict in prior Ninth Circuit opinions, and in those of other circuits, concerning application of the "unless clearly erroneous" mandate of Rule 52(a). Attempting to lay down specific criteria for interpreting the rule, the court, building on Duberstein, declared:

A finding of fact, to which the clearly erroneous rule applies, is a finding based on the "fact-finding tribunal's experience with the mainsprings of human conduct." A conclusion of law would be a conclusion based on application of a legal standard. . .

In the principal case the finding of mutual mistake can be fairly said to be derived not solely from application of legal standards, but from the trial judge's experience with human affairs. ${ }^{106}$

The Lundgren test for distinguishing law from fact for Rule 52(a) purposes is unworkable. Its deficiencies are apparent when the test is apphed to the question whether undisputed facts should be characterized as neghigence. Such a determination would be "based on . . . experience with the mainsprimgs of human conduct." But it would equally be "based on application of a legal standard," the reasonably prudent man concept.

Subsequent Ninth Circuit decisions show that the inadequacy of the Lundgren bifurcation is not limited to cases concerning the reasonableness of given conduct. In Fleischmann Distilling Corporation v. Maier Brewing Company, ${ }^{107}$ the holder of the "Black \& White" trademark for Scotch whisky sought an injunction restraming defendants from selling "Black \& White" beer. A Ninth Circuit panel including Judge Duniway reversed the trial judge's denial of relief, making an independent determination whether, in terms of the Lanham Act, defendants' use of the name was "likely to cause confusion or mistake or to deceive purchasers as to the source of origin" of the product. ${ }^{198}$ Citing Lundgren, the court reasoned that "this determination of likelihood of confusion partakes more of the cliaracter of a conclusion of law than of a finding of fact. The inference [s] to be drawn from the undisputed facts here are 'derived from application

198307 F.2d at 115.

197314 F.2d 149 (9th Cir.), cert. denied, 374 U.S. 830 (1963).

198 Lanham Act $\S 32$ (1) (a), 60 Stat. 437 (1946), as amended, 15 U.S.C. $\$ 1114$ (1963). See 314 F.2d at 151-52. 
of a legal standard." "199 However, the court clearly had to apply its "experience with the mainsprings of human conduct" to reach the conclusion that "the average purchaser ... would be likely to believe ... that the maker of the beer had some connection with the concern which had produced the well known Black \& White Scotcli whisky."200

Similarly, in Kippen v. American Automatic Typewriter Company, ${ }^{201}$ a different Ninth Circuit panel, relying on Lundgren, held that a trial court's conclusion that a manufacturer had "good cause" to terminate a distributorship contract because of plaintiff's alcoholism was one "of law since it was based at least in part upon the application of a legal standard."202 Again, such a determination, like most apphications of legal standards not cast in technical terms, requires a judge to draw upon his knowledge of life. ${ }^{203}$ The result of free reviewability in Fleischmann and

199314 F.2d at 152; accord, e.g., Sears, Roebuck \& Co. v. Johnson, 219 F.2d 590 (3d Cir. 1955). Contra, e.g., Sun-Maid Raisin Growers v. Sunaid Food Products, Inc., 356 F.2d 467 (5th Cir. 1966) ; Beatrice Foods Co. v. Neosho Valley Cooperative Creamery Ass'n, 297 F.2d 447, 449 (10th Cir. 1961) ("The determination of whether these two trade names are confusingly similar is a question of fact.") ; Dwinell-Wright Co. v. National Fruit Prod. Co., 140 F.2d 618 (1st Cir. 1944). For a Ninth Circuit case inconsistent with Fleischmann, see Oriental Foods, Inc. v. Chun King Sales, Inc., 244 F.2d 909, 915 (9th Cir. 1957); cf. Audio Fidelity, Inc. v. High Fidehty Recordings, Inc., 283 F.2d 551, 557-58 (9th Cir. 1960).

200314 F.2d at 155 . We may wonder how the Ninth Circuit can reconcile this decision with its holdings of limited review in the negligence cases. See notes 63-66 supra and accompanying text.

201324 F.2d 742 (9th Cir. 1963). See note 141 supra and accompanying text.

202324 F.2d at 745. Finding no good cause for the termination, the court of appeals reversed. In striking contrast to Kippen is Snider v. England, 374 F.2d 717, 720 (9th Cir. 1967). In this case, the Ninth Circuit, citing Lundgren and ignoring Kippen, held that the ultimate determination of "reasonable cause" was not freely reviewable, because "the finding . . . is 'based on the "fact-finding tribunal's experience with the mainsprings of human conduct." " "

203 Thus, in Lundgren, the court cited a series of Ninth Circuit cases which were described as supporting the position of free reviewability. The court claimed that "in all these cases the inferences drawn from the undisputed facts seem to have been inferences derived from application of a legal standard and not inferences derived from having had 'experience with the mainsprings of human conduct." 307 F.2d at 115 . This assertion is most questionable. Of the nine cases in point referred to by the court, six clearly involve, at least in part, a decision maker's utilizing his "experience with human affairs." Id. See One, Inc. v. Olesen, 241 F.2d 772 (9th Cir. 1957), rev'd, 355 U.S, 371 (1958) (whether magazine obscene) ; National Lead Co. v. Wolfe, 223 F.2d 195 (9th Cir.), cert. denied, 350 U.S. 883 (1955) (whether "Dutch Boy" trademark for paint infringed by sale of "Dutch Paint"; confusing similarity held to exist); Stevenot v. Norberg, 210 F.2d 615 (9th Cir. 1954) (whether reinstatement of stockholder-employees, discharged by trustee, would be in best interests of debtor); Besig v. United States, 208 F.2d 142 (9th Cir. 1953) (whether books obscene); Plomb Tool Co. v. Sanger, 193 F.2d 260 (9th Cir. 1951), cert. denied, 343 U.S. 919 (1952) (whether plaintiff should be characterized as independent contractor, or employee of defendant); Brown v. Cowden Livestock Co., 187 F.2d 1015, 1018 (9th Cir. 1951) (whether plaintiff abandoned claim against defendant by accepting check of plaintiff's alleged agent to 
Kippen is sound, not because of the Lundgren test, but because an appellate court should not be compelled to defer to a trial judge's application of law based on experience with liuman affairs. ${ }^{204}$

\section{CONCLUSION}

Despite the basic and recurring nature of the problem, both federal and state courts are badly confused on the scope of review to be accorded a trial judge's application of a legal standard to undisputed or established historical facts. The phrases "question of law" and "question of fact" have no real meaning in this area, and have been used simply as synonyms for free review and limited review respectively. Conflicting looldings abound, the courts laving evolved verbal formulae whicl are themselves inconsistent. One line of cases states that, since the facts are undisputed, only questions of law are presented, ${ }^{205}$ while another line proclaims the existence of a question of fact, when different conclusions can reasonably be drawn froin nonconflicting evidence. ${ }^{206}$ Clearly the first step in reform is to abandon such use of the law-fact terminology and to recognize law application as sui generis. The second step is to recognize that precedents dealing with the scope of review of jury verdicts should not control nonjury cases. The third step is to grant free reviewability to the product of applying law to fact.

A related question is the desirable scope of review of truly factual determinations, when based on undisputed circumstantial evidence or on evidence not given orally in open court. In deciding such an issue, the trial judge has no advantage over the appellate court, a factor which suggests free reviewability. Nevertheless, it is recognized that both the intent of the draftsmen of Rule 52(a) and cases like Duberstein militate

whom defendant had made payment; "no dispute as to what happened"). The remaining three cases are more technical in nature. See Pacific Vegetable Oil Corp. v. Commissioner, 251 F.2d 682 (9th Cir. 1957) (whether purchase by corporation of stock held by taxpayer constitutes distribution of taxable dividend or distribution in partial hquidation); Kwikset Locks; Inc. v. Hillgren, 210 F.2d 483, $488-89$ (9th Cir.), cert. denied, 347 U.S. 989 (1954) (whether defendant's product infringed plaintiff's product; "no dispute as to the evidentiary facts"); Kemart Corp. v. Printing Arts Research Labs., Inc., 201 F.2d 624, 627-28 (9th Cir. 1953) (whether litigant's process infringed opponent's patent).

204 Another Ninth Circuit opinion has interpreted Lundgren as a general restraint on broad review: "[T]he established rule, recognized by this court [in Lundgren], is that in respect to inferences drawn from undisputed facts the findings may not be set aside unless found to be clearly erroneous." Stauffer Laboratories, Inc. v. FTC, 343 F.2d 75, 78 (9th Cir. 1965).

$\therefore \quad 205$ E.g., RKO Teleradio Picturés, Inc. v. Franchise Tax Bd., 246 A.C.A. 948, 952-53, 55 Cal. Rptr. 299, 302 (1966), and cases there cited; Shultes v. Halpin, 33 Wash. 2d 294, 306, 205 P.2d 1201, 1207 (1949).

208.E.g., Lundgren v. Lundgren, 245 A.C.A. 604, 608, 54 Cal. Rptr. 30, 33 (1966) ; Industrial Indèm.' Co. v. Golden State Co., 117 Cal. App. 2d 519, 537-38, 256 P.2d 677, 689 (1953); Husky Hi-Power, Inc. v. Salt Creek Freightways, 366 P.2d 1003, 1006-07 (Wyo. 1961). 
against this result. Moreover, considerations of uniformity, which point toward free review of law application, are not as compelling when the question presented is reconstruction of a unique set of events or conditions. Accordingly, a workable compromise, which might appease those concerned about the prestige of lower courts, would be to grant restricted review in this truly factual area, but free review of law application. If this solution is adopted, courts will have to be far more discriminating than they have been to date in distinguishing between ascertainment of historical facts, and evaluation of such facts in terms of their legal consequences. 


\section{California Law Review}

\begin{tabular}{|c|c|}
\hline Vor. 55 & OCTOBER 1967 \\
\hline
\end{tabular}

\section{BOARD OF EDITORS}

Editor-in-Chief

Peter Kax Westen

Managing Editor

JoHN JACKSON BENTLEX III

\begin{abstract}
Article Editors
ArTson M. GREx

Jomn F. Pritchard

Research and Chief

Note \& Comment Editor

George Richard PoenNer

Book Revieve Editor

WIIIIAM ROger StreIOW

Executive Editor

Danier U. Samte
\end{abstract}

\author{
Note \& Comment Editors \\ Paut B. Bergman \\ STEPHEN J. BisGeIER \\ Ttmothy Dreyfus \\ Mictaet C. Ferguson \\ Emen HaLl Guggenamie \\ Donatas Januta \\ Mark ReutLINGer \\ JeFrRey David Sodex \\ Wretrams T. Vukowich
}

Associate Editors

BRUCE Babcock, JR.

JEFEREY F. BECK

WIILIAMI S. BETEARD

LAWRENCE L. CuRTice

STEVEN H. GoldFarb

Robert EARNest GYeMant

RICHARD V. Hatr

Atan E. Harris

Dougras A. Hayder

JOHN E. HUERTA

WIIITAMM L. JAEGER

\section{Candidates}

SAMTUEL Bassett AbBotT JAMIES ROBERTSON BUTLER, $\bigcup_{R}$.

ROBERT D. BYRNE, $\int_{R}$.

JAMES H. Christiansen

KenNetr A. CoHeN

STEVEN W. ERICKSON

RICHARD N. Fisher

MAX W. J. GraHAM, Jr. PaUL Harris
JomN A. Hosknss

RICHARD L. KINTZ

RICHARD I. LEHER

A. KEITH LESAR

STEPHEN M. LOWE

Michaex H. Marcus

LeONard I. Margolis

Fred Minder

ROBERT E. MONTGOMERY, JR.
Blaine Covangton Jantn Mrchael Justin Myers Douglas M. Schwab JANet FrIednan Stansby KristzNe MARY StrachaN

JOHN K. MORRIS Patricta A. Muszynser Clayton C. Patrick JoHN M. POSWaLL James E. Reed Barbara A. Rhine BRENT NELSON RUSHForth Stuart P. Tobisman DAVID S. WEISSBRODT

\section{Secretary}

Susar G. VeGa 